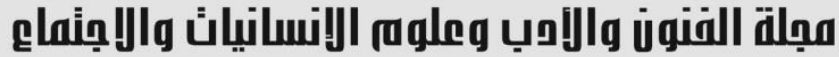

Journal of Arts, Literature, Humanities and Social Sciences www.jalhss.com

\section{دور منظمات حقوق الإنسان في الحد من ظاهرة عمالة الأطفال}

\author{
د. فوزية القضيبي \\ أستاذ مساعد بكلية أللغة العربية والدار استات الاجتماعية ـ جامعة القصيم ـ قسم علم اجتماع والخدمة

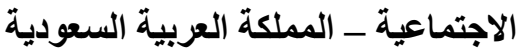 \\ البريد الأكتروني: rem488@ hotmail.com
}

الملخص

هدف البحث الحالي إلى التعرف على أسباب ظاهرة عمالة الأطفال، ودور منظمات حقوق الإنسان في القضاء على ظاهرة عمالة الأطفال، وقد تكونت عينة البحث من (100) عامل من العاملين بالجمعية الوطنية لحقوق الإنسان بالمملكة العربية السعودية، وقد تبنى البحث المنهج الوصفي، واستعان بالاستبانة كأداة للبحث، وقد توصل البحث إلى أن المتوسط العام للمحور الأول قد جاء بدرجة استجابة (عالية)، وبمنوسط حسابي قدره (3.81)، و انحر اف معياري (1.150)، وأن المتوسط العام للمحور الثاني قد جاء بدرجة استجابة (متوسطة)، وبمتوسط حسابي قدره (3.10)، و انحر اف معياري (0.627)، و أوصى البحث بوضع قو انين تمنع عمالة الأطفال أقل من 10 سنو ات، وتقديم الدعم المالي للأسر الفقيرة. الكلمات المفتاحية: منظمات حقوق الإنسان، عمالة الأطفال. 
 \\ $=-{ }_{m}$ \\ The Role of Human Rights \\ Organizations in Reducing Child Labor Phenomenon
}

\author{
Dr. Fozyah Alqadhibi \\ Assistant Professor, College of Arabic Language and Social Studies - Qassim University \\ - Department of Sociology and Social Work - Kingdom of Saudi Arabia \\ Email: rem488@hotmail.com
}

\begin{abstract}
This research aimed to identify the causes of the child labor phenomenon, its effects, and the role of human rights organizations in eliminating the child labor phenomenon. The research sample consisted of (100) workers from the National Society for Human Rights (NSHR) in the Kingdom of Saudi Arabia. The research adopted the descriptive method and used the questionnaire as the research tool. The research concluded that the overall mean of the first axis gained a (high) response degree, with an arithmetic mean of (3.81), and a standard deviation (1.150). Also, the overall mean of the second axis gained a (medium) response degree, with an arithmetic mean of (3.10), and a standard deviation of (0.627). The research recommended establishing laws prohibiting child labor under 10 years and providing financial support to poor families.
\end{abstract}

Keywords: Human Rights Organizations, Child Labor. 


\begin{tabular}{|c|c|c|c|}
\hline 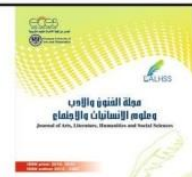 & 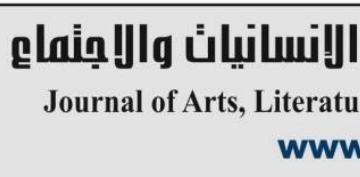 & 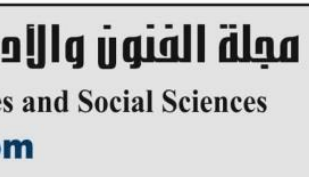 & \\
\hline$=$ & Volume (68) June 2021 & العدد (68) يونيو 2021 & \\
\hline
\end{tabular}

مقدمة

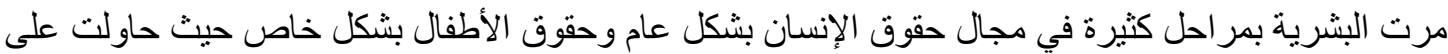

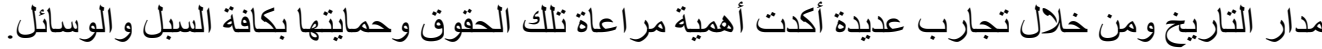

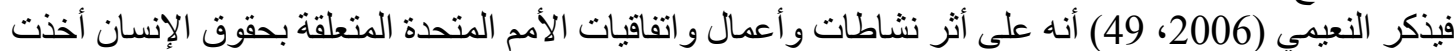

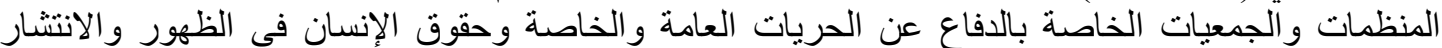

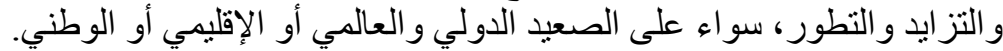

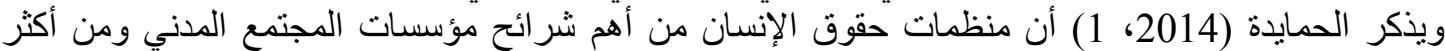

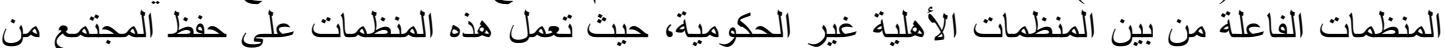

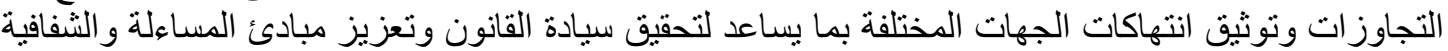

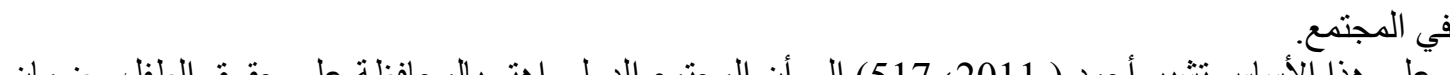
و على هذا الأساس تثير أحمد ( 2011، 517) إلى أن المجتمع الدولي اهتم بالمحافظة على حقوق الطفل وضمان

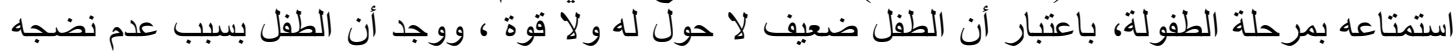

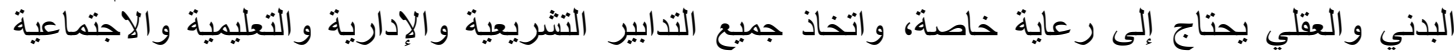

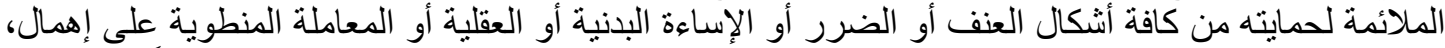

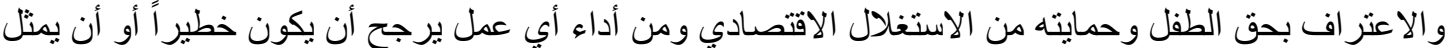

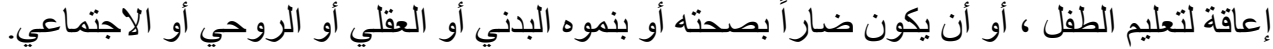

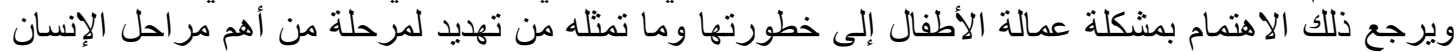

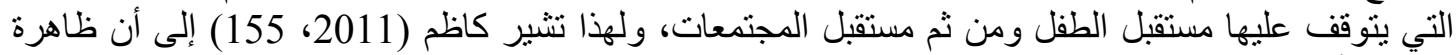

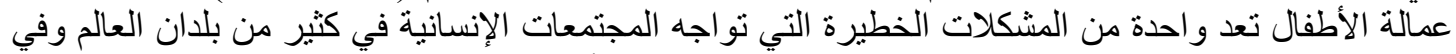

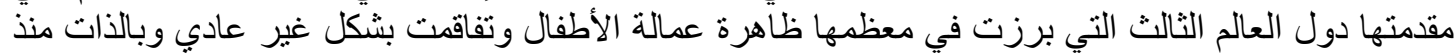

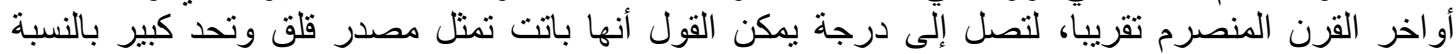

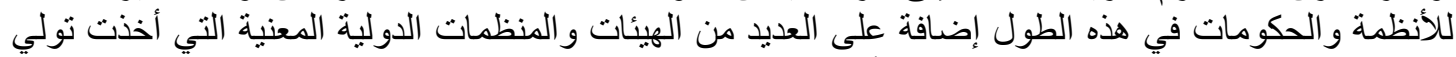

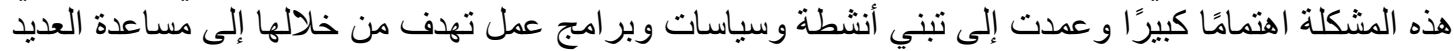

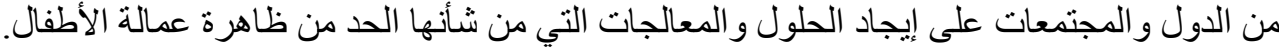

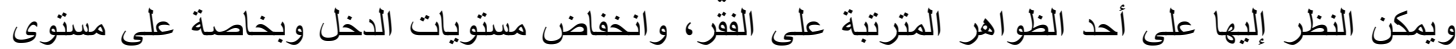

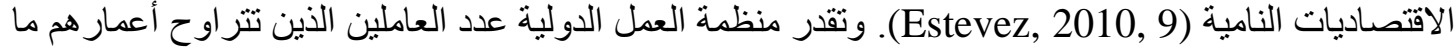

بين (17-5) عامًا بما يقرب من (246) مليون طفل (Weston \& Teerink, 2006, 1).

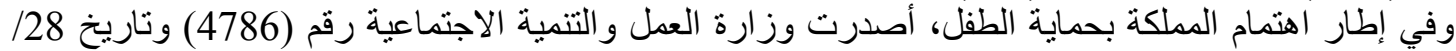

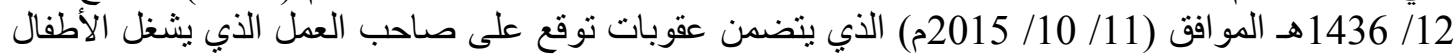

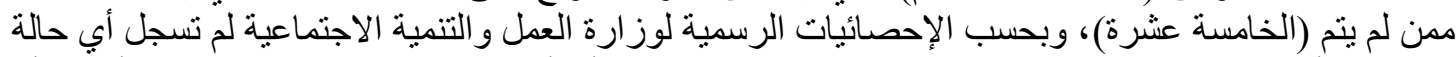

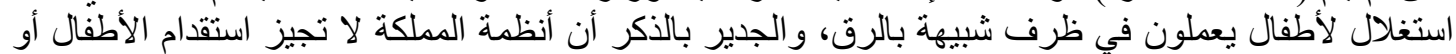

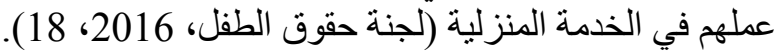

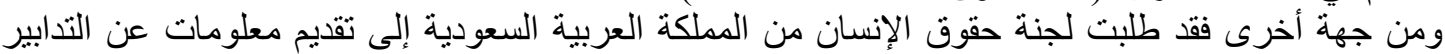

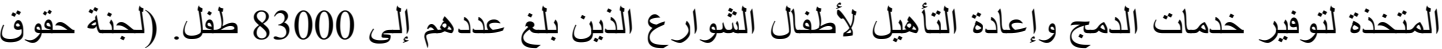

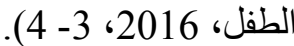

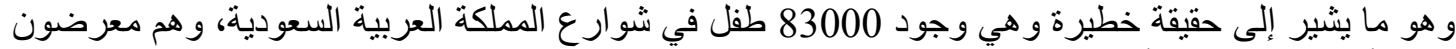

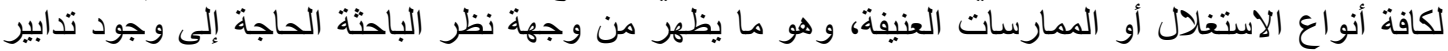

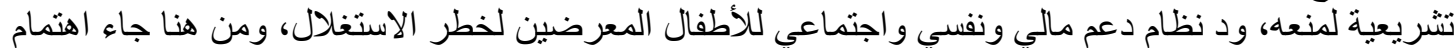

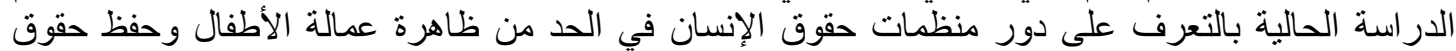

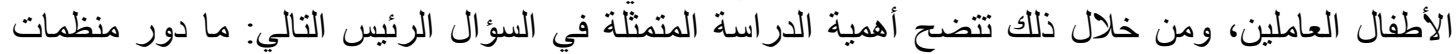
حقوق الإنسان في الحد من ظاهرة الإن عمالة الأطفال؟ الإن

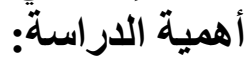
تظهر أهمية الدر اسة في العديد من الجوانب تتمثل فيما يلي: 


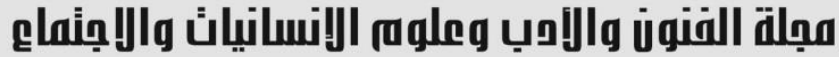

Journal of Arts, Literature, Humanities and Social Sciences www.jalhss.com

- أهية مرحلة الطفولة في بناء شخصية الإنسان وسلوكه في المستقبل بما يقتضي العمل على توفير أفضل

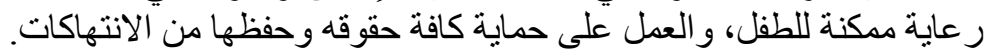

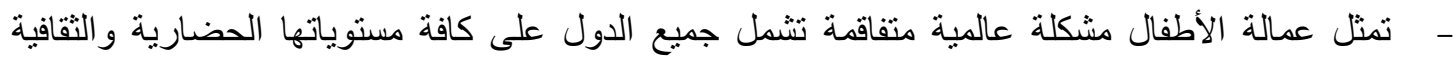

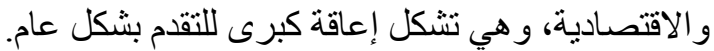

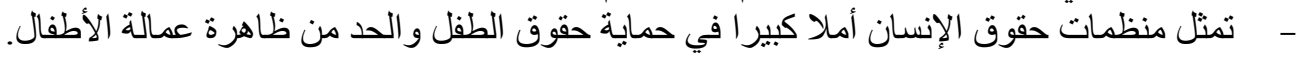

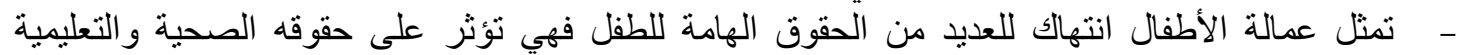
بالإضافة إلى حقه بالثعور بطفولته والتمتع بها كغيره من الأطفال الذين يعيشون في الذي حياة طبيعية كغير هم من

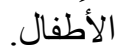

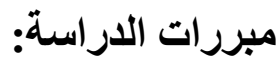
1. نظر لانتشار ظاهرة عمالة الاطفال في المملكة العربية السعودية رأت الباحثة تسليط الضوء على هذه

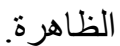

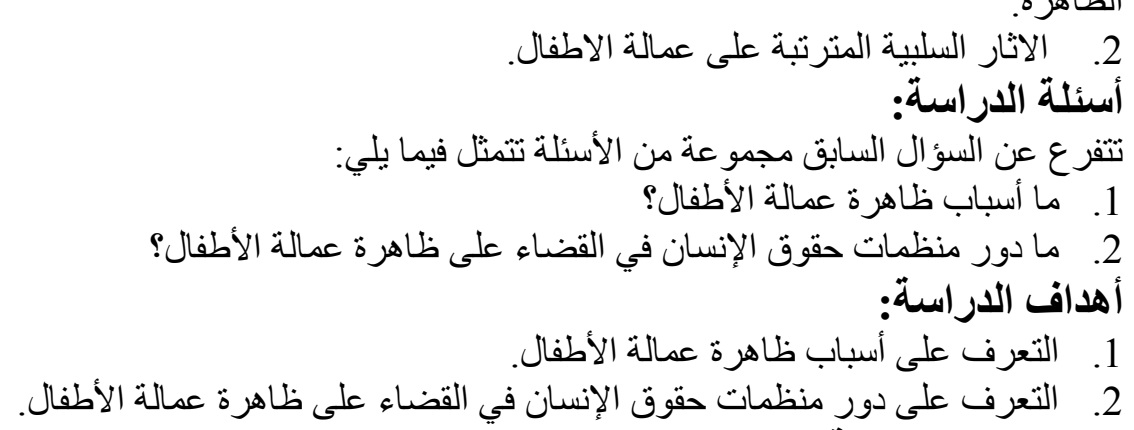
مصطلحات الاراسة: تعرف محمد (2012، 1470) الدور بأنه مجموعة المهام والمسئوليات والأنشطة التي يقوم بها المسئولين

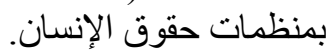
حقوق الإنسان يعرفها شفلوت (2013، 18) بأنها مجموعة المبادئ والقيم الأخلاقية والمزايا الإلهية الممنوحة لكل إنسان،

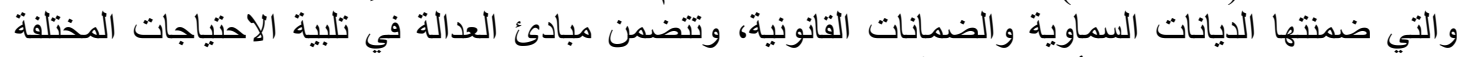

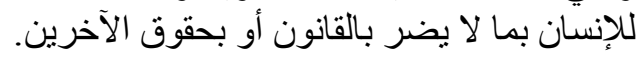

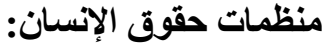

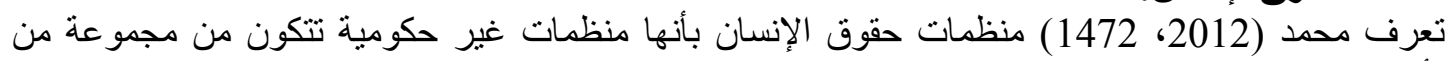

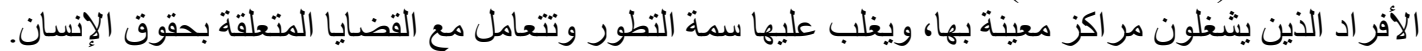

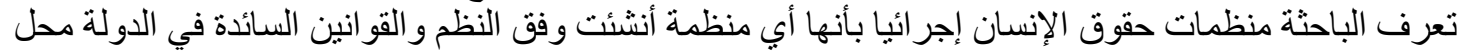

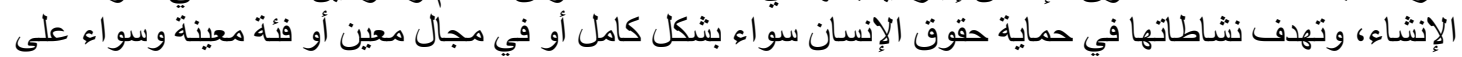
عمالة الأطفال وطني أو إقليمي أو دولي.

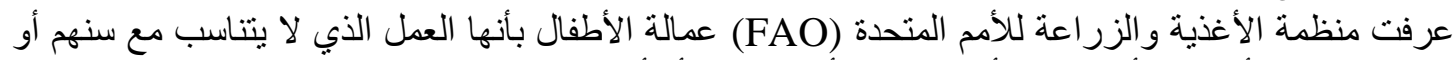

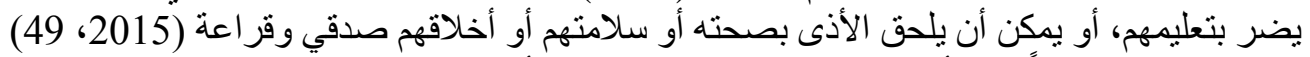

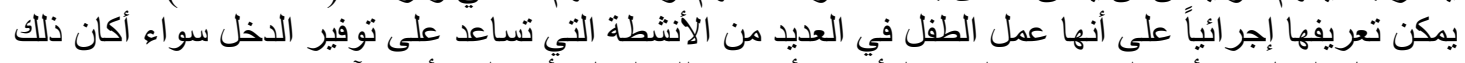

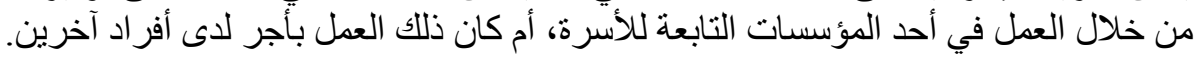

\section{الإطار النظري المبحث الأول: عمل الأطفال في المواثيق والمعايير الاولية:}

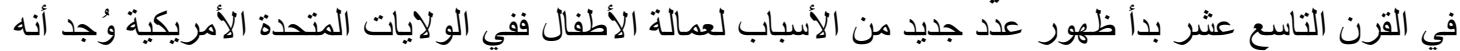

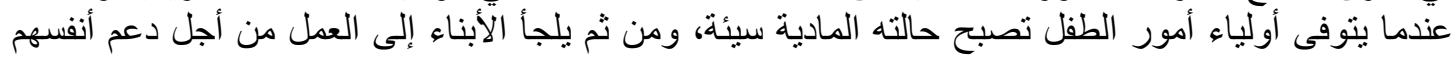




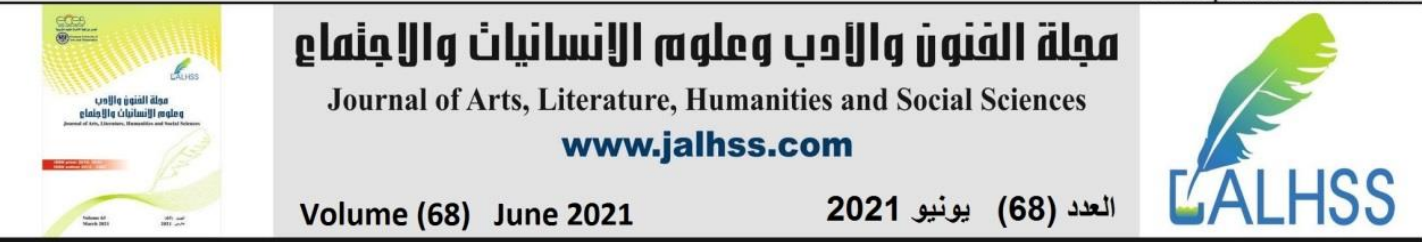

ودعم أسر هم، و هنا نجد أن الأو لاد عادة ما يلجئون إلى العمل في المصانع أو في مناجم الفحم. , Rai, 2016)

وقد بدأ الاهتمام بظاهرة عمالة الأطفال بعد إنشاء منظمة العمل الدولية (ILO) Organization

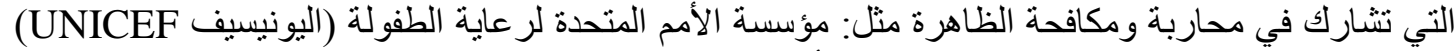

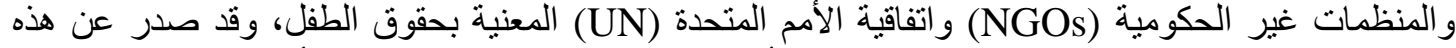

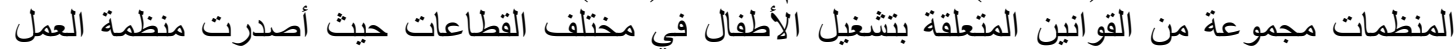

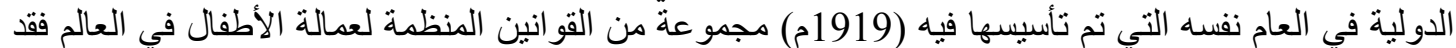
صدرت الاتفاقية رقم (5) بشأن الحد الأدنى للسن التي يجوز فيها تشغيل الأحداث في الأعمال الصناعية

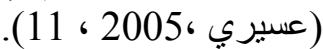
وقد صدرت العديد من المو اثثيق والمعاهدات الخاصة بحماية حقوق الأطفال ومن بينها ميثاق الأمم المتحدة

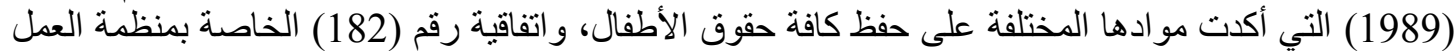

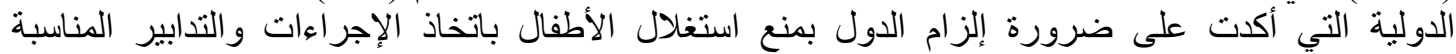

(Grossman- Greene \& Bayer, 2009, 6)

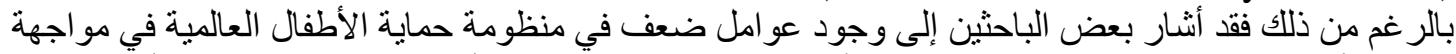

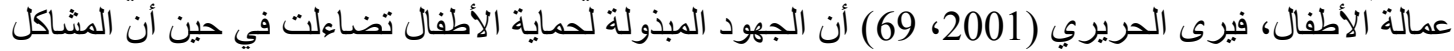

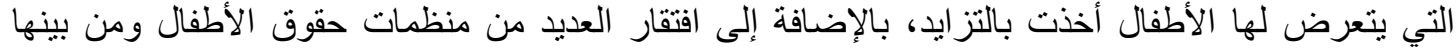
منظمة العمل الدولية للسلطة التنفيذية.

تعريف الطفل كما جاء في اتفاقية حقوق الطفة الطفل:

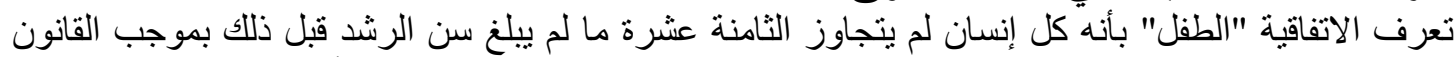

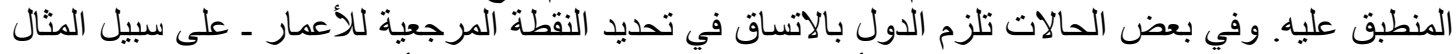

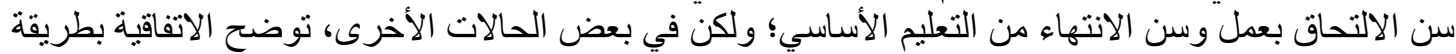
لا لبس فيها الحد الأعلى للأعمار مثل تطبيق عقوبة السجن مدى الحياة أو الإعدام لمن هم دون سن الثامنة عشر الأن

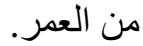

من أهم المنظمات والجهات ذات الاهتمام بقضايا حقوق الطقل:

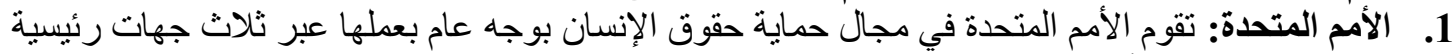

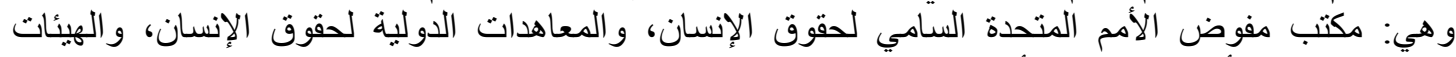

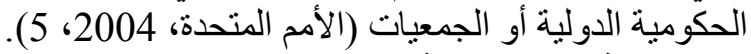

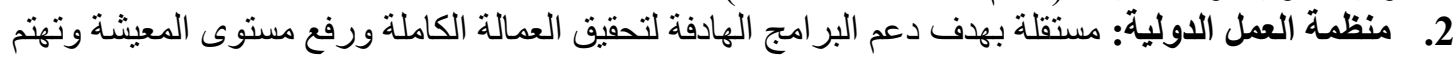

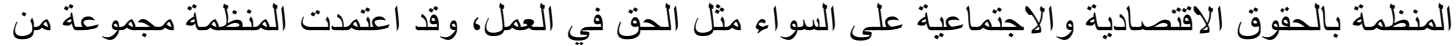

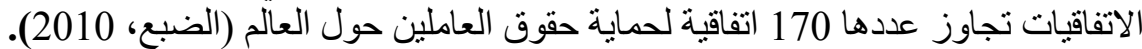

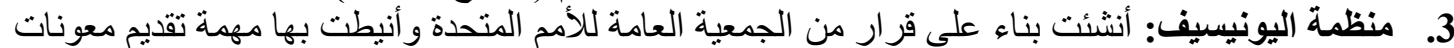

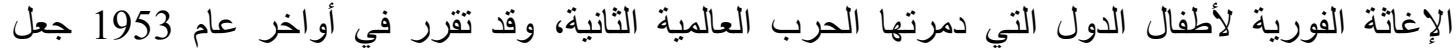

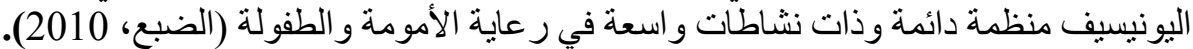

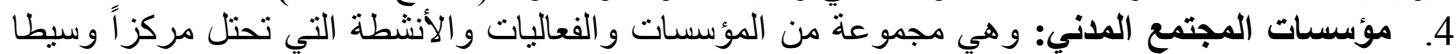

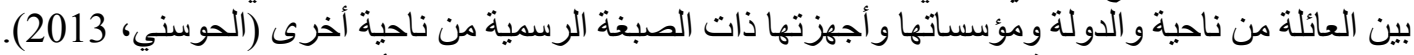

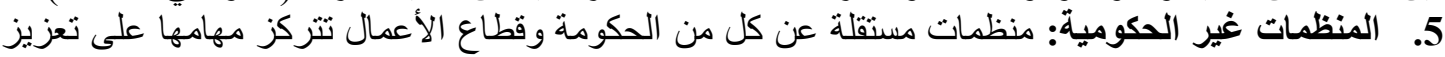

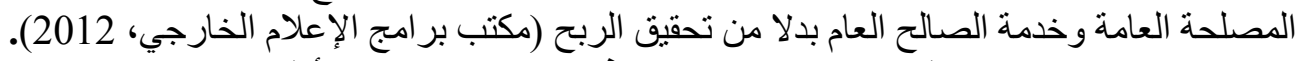

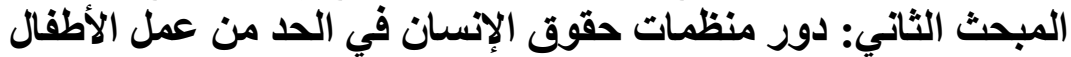

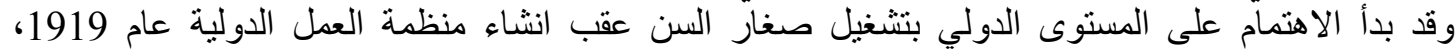
وصدرت أول اتفاقية برقم 5 لسنة 1921 بتحديد سن الر ابعة عشر لتشغيل الاحداث في الاعمال الصنال الصناعية، ثم

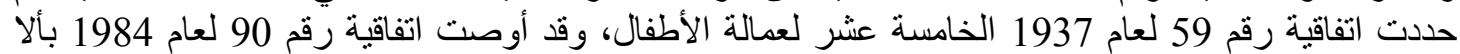

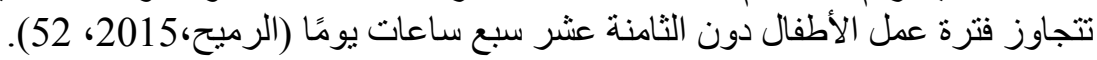




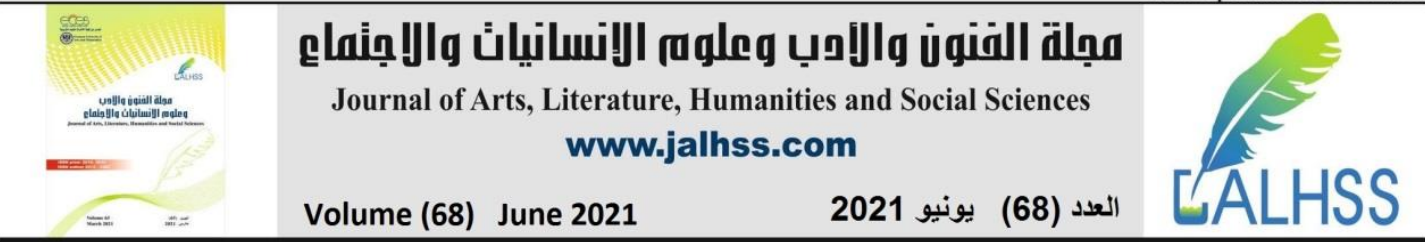

ويمكن توضيح دور هذه المنظمات من خلال ما يلي: الرئ

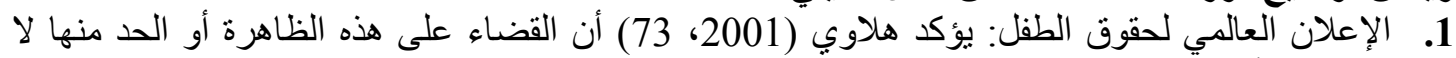

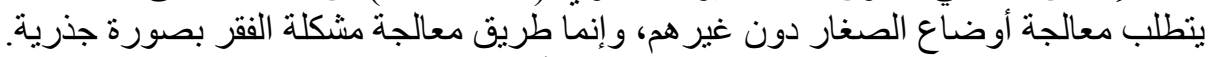

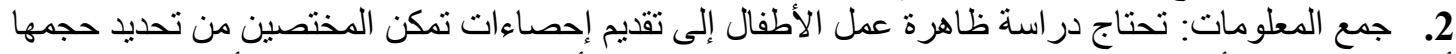

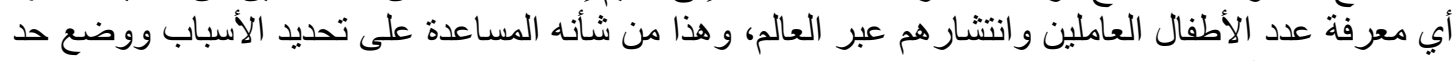

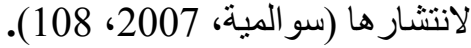

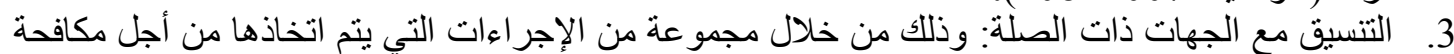

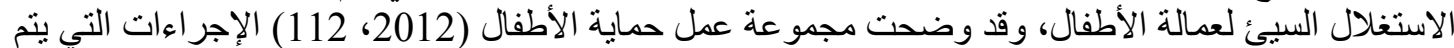
اتخاذها بالتنسيق مع الجهات المعنية بحماية حقوق الطفل في حالات الطات الطو الارئ.

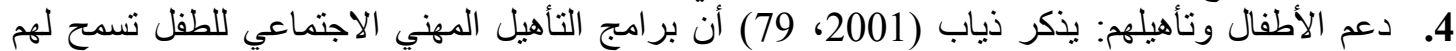

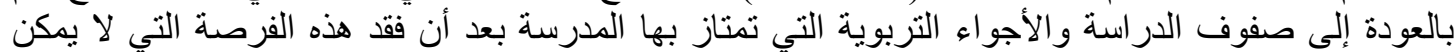
5. دعم الأسر الفقيرة: يعتبر فقر الأسرة السبب المباشر لظاهرة عمالة الأطفال، وقد أوصت اللجنة الدولية

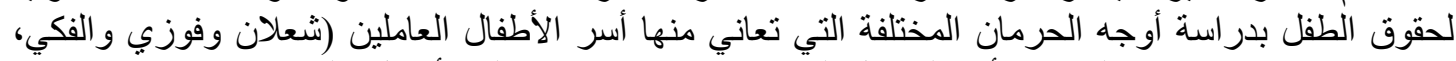
2011، 70)، حيث يعثبر الفقر من أهم العو امل التي تتنج عنها ظاهرة عمالة الأطفال (الرميح، 2015). ثانياً: الدراسات السابقة دراسة رزق الله (2015) بعنوان "واقع عمالة الأطفال في الجزائر دراسة ميدانية لعينة من الأطفال بولاية تبسة" دراسلة هذفت الدراسة إلى التعرف على أهم أسباب عمالة الأطفال عينة الدراسة، و التعرف على المخاطر التي يتعرض

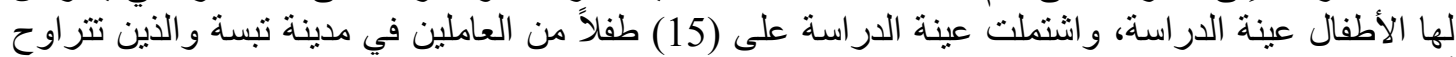

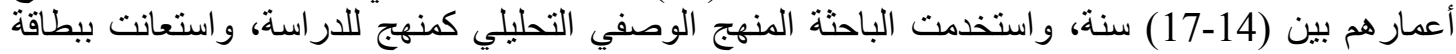

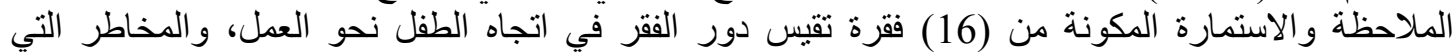

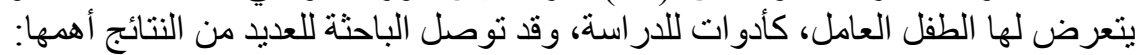

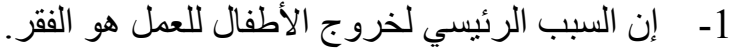

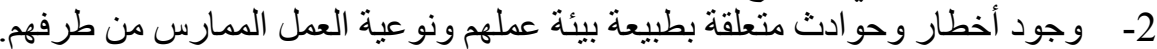

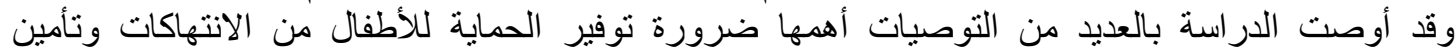

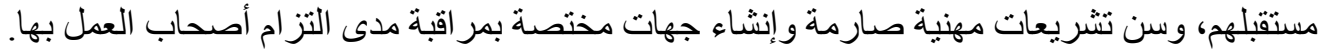
دراسة فدعم ومحمد (2013) بعنوان "مخاطر عمل الأطفال في جمع النفايات دراسة ميدانية في مدينة

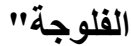

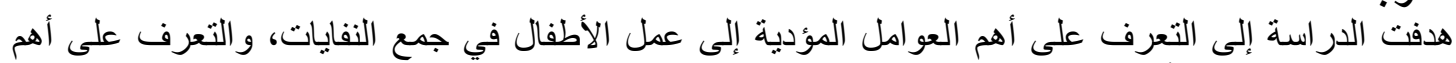

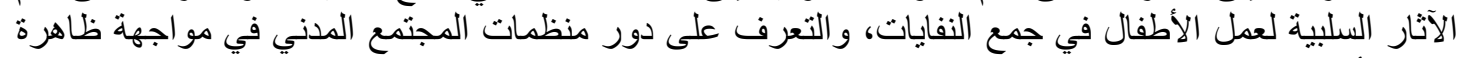

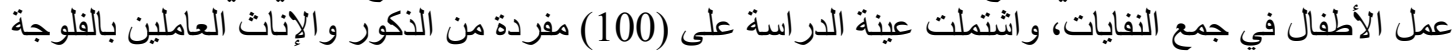

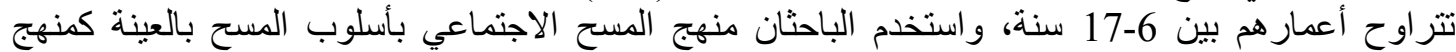

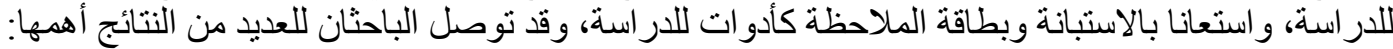

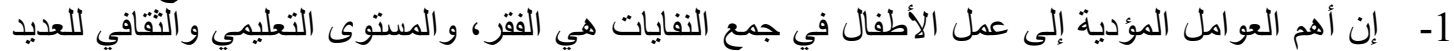
من الأسر، وضعف الأه الهتمام بنظافة المدينة. 2- إن أهم الآثار السلبية لعمل الأطفال في جمع النفايات هي تدهور العلاقات الأسرية وشيوع الخلافات، و التحرش الجنسي، و ألثياب الرقابة الأسرية.

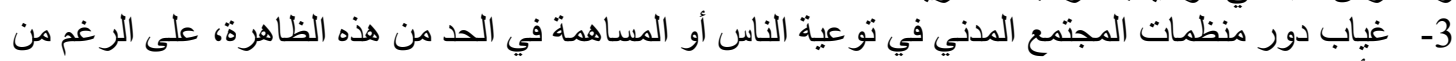
ازدياد أعدادها بشكل لافت للنظر.

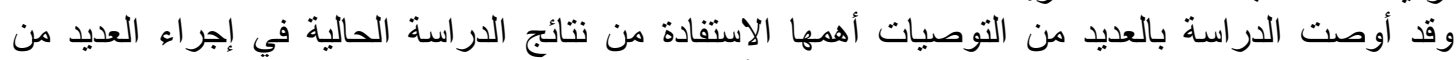

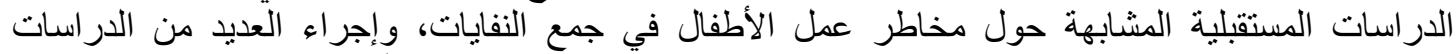

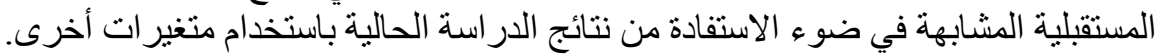




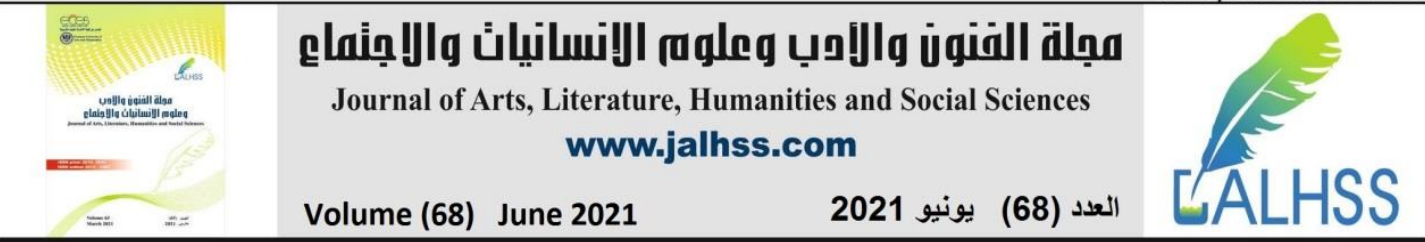

دراسة شهاب (2012) بعنوان "الأسباب المؤدية إلى عمل الأطفال دراسة ميدانية في مدينة بغداد"

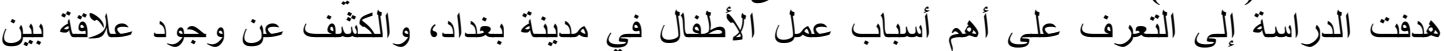

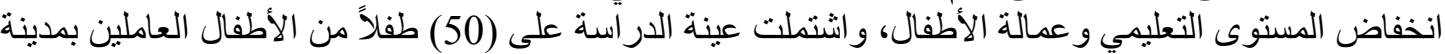

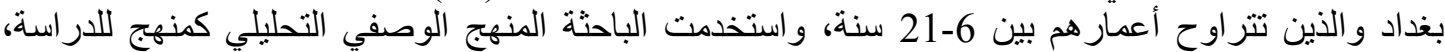

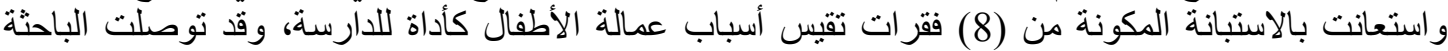

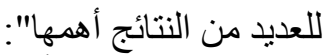
1- يعتبر الفقر من أهم الأسباب المؤدية إلى عمل الأطفال، وكثرة المشكلات الأسرية.

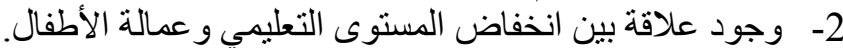

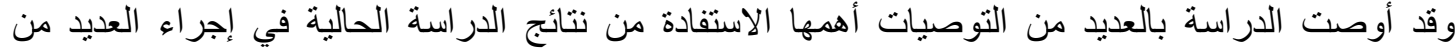

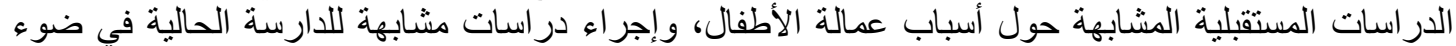

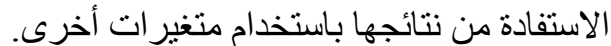

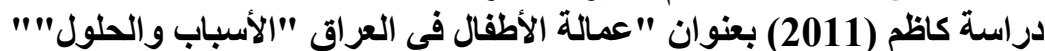

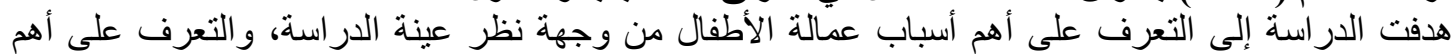

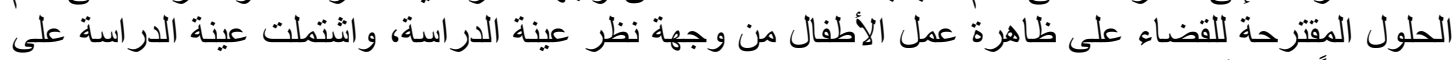

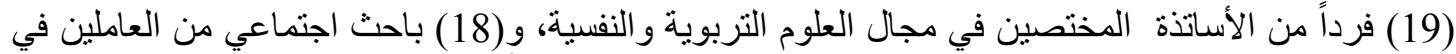

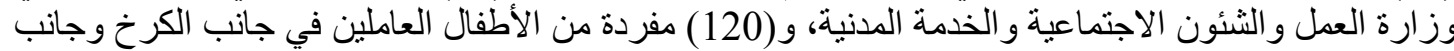

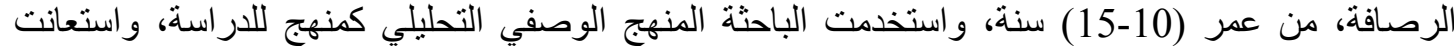

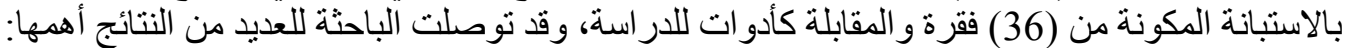

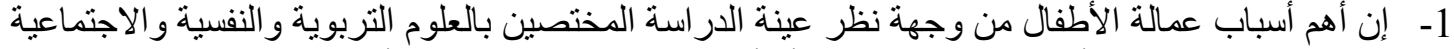

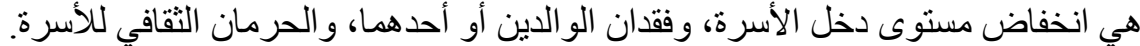

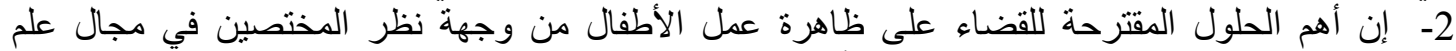

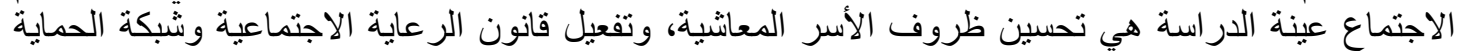

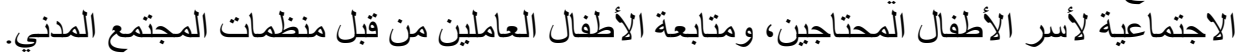

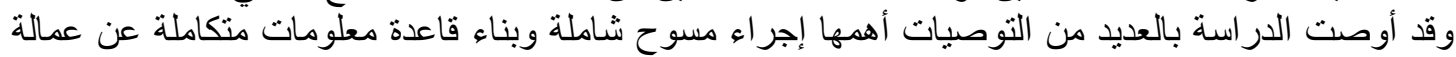

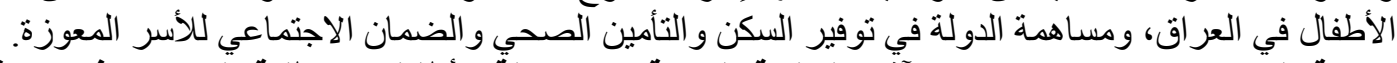
دراسة الثياب (2006) بعنوان "الآثًار السلبية الناتجة عن عمالةً الأطفال من طلبة المدارس لارس في محافظة

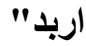
هدفت الدراسة إلى التعرف على الآثار السلبية الناتجة عن عمالة الأطفال من طلبة المدارس في محافظة اربد،

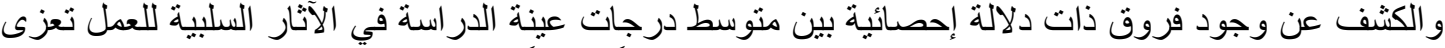

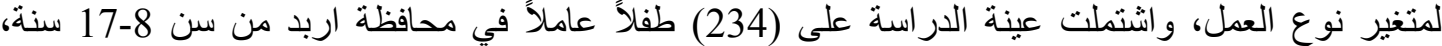

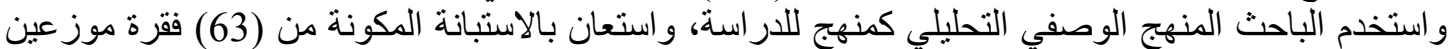

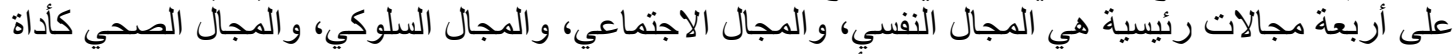

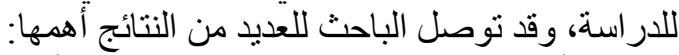

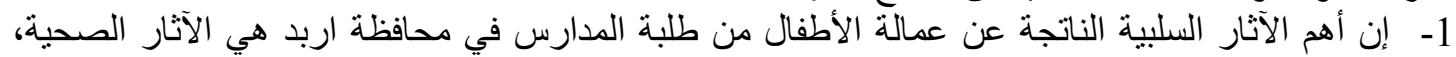
والآثار الاجتماعية، والآثار النفسية ثم السلوكية.

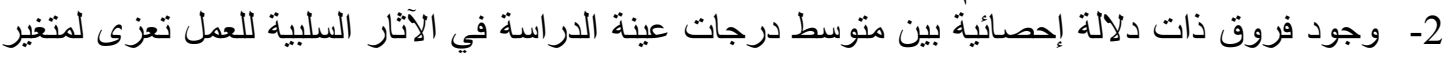

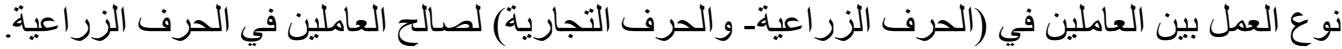

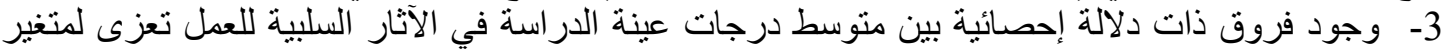

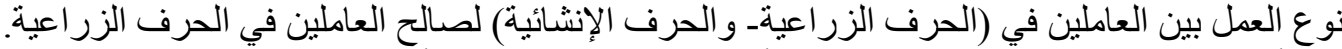

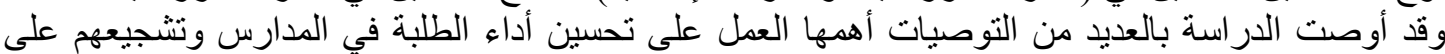
البقاء في المدرسة من خلال مساعدة الأسر الفقيرة التي تعتمد على دخل التيل الطفل العامل، وتفعيل قانون التعليم

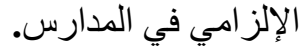




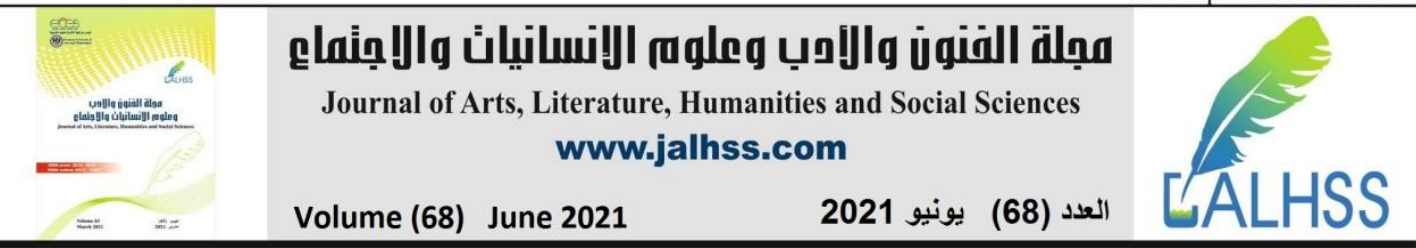

دراسة وانجوسا (Wangusa, 2013) بعنوان: " الثركات متعددة الجنسيات، حقوق الإنسان وعمل الطقل في غانا".

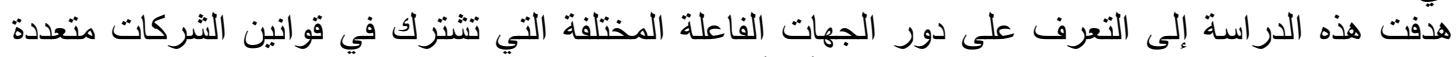
الجنسيات، وكيفية تحقيق المحتوى الموضوعي لأي أجندة تنظيمية، وبحث جانب النوع النية في قضية التية عمل الطفل،

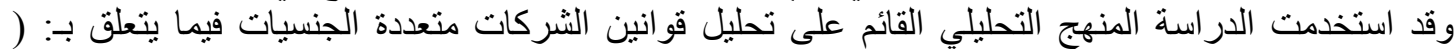

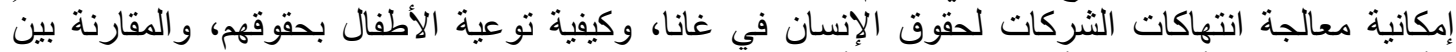

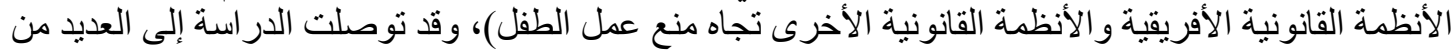

1- أن القضاء على عمل الطفل يتضمن بالضرورة تعزيز رفاهية الطفل. 2- ت توجد علاقة ارتباطيه بين الدول المتخلفة في أهداف التعليم والدول التي يزدهر فيها عمل الطفل مثل باكستان

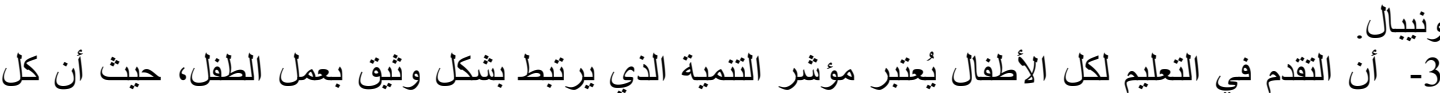
طالب بدو ام كامل بقلل احتمالية عمل الطفل. 4- أن دمج شُئون عمل الطفل في استراتيجيات التنمية القومية، ودعمها بتشريع فعال، هو المسار الأفضل

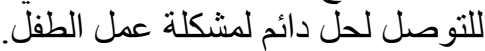

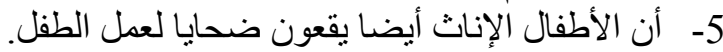

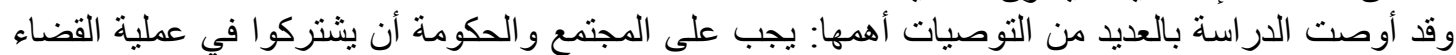
على عمل الطفل، وضرورة إتباع دنهج قائم على الحقوق فيما يتعلق بعمل الطفل بالاعتماد على القواني النين

وتطبيقها.

دراسة أمون وآخرين (Amon et al., 2012) بعنوان: " عمل الطقل والصحة البيئية: التزامات الحكومة

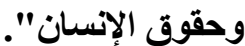

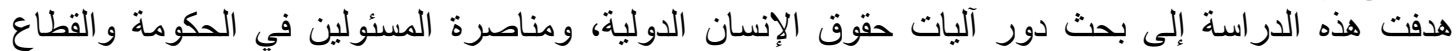

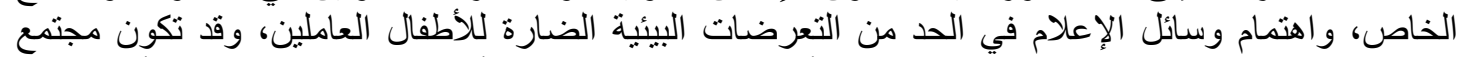

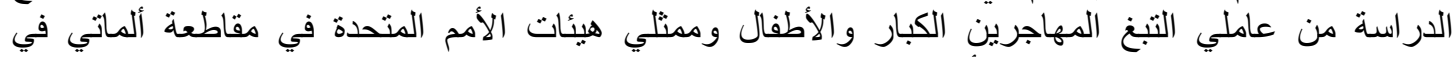

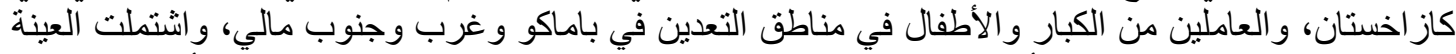

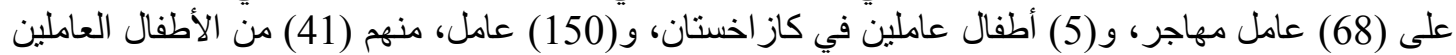

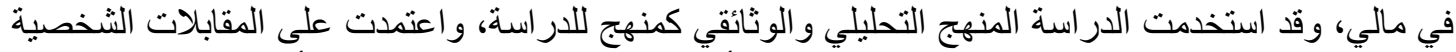

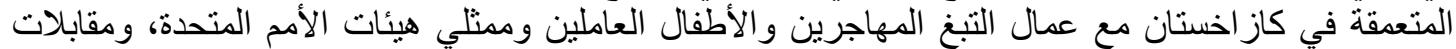

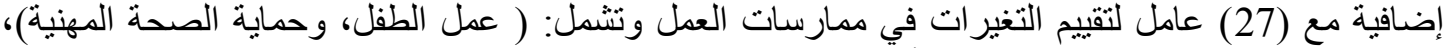

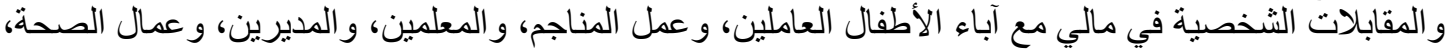

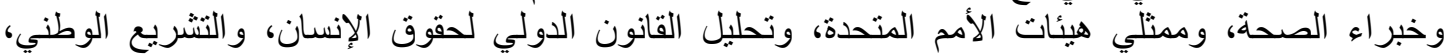

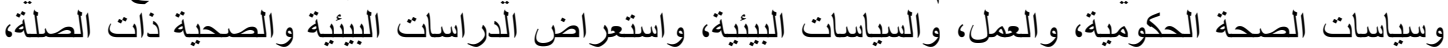

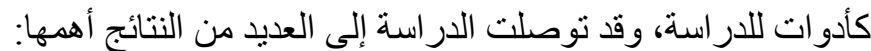

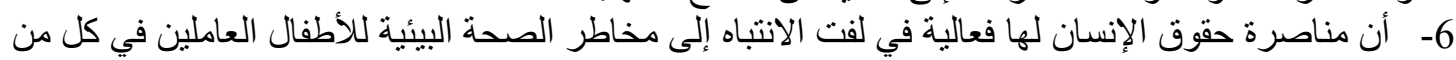

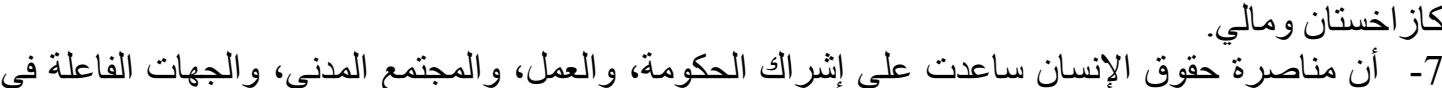

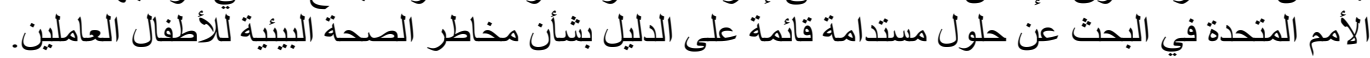

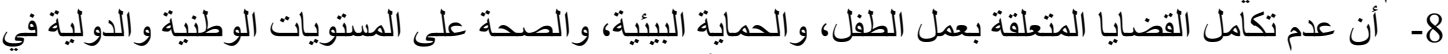

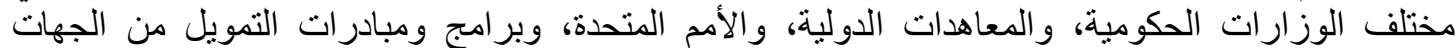

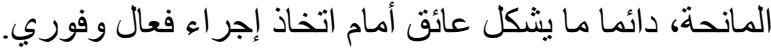

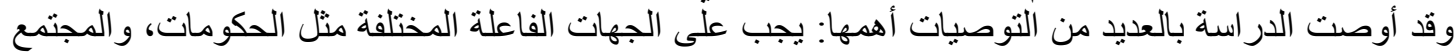

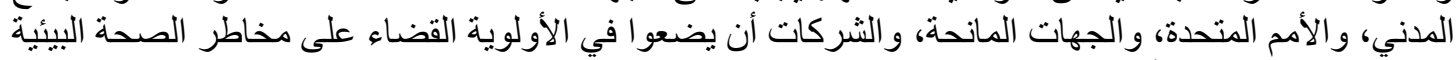

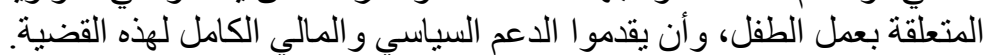




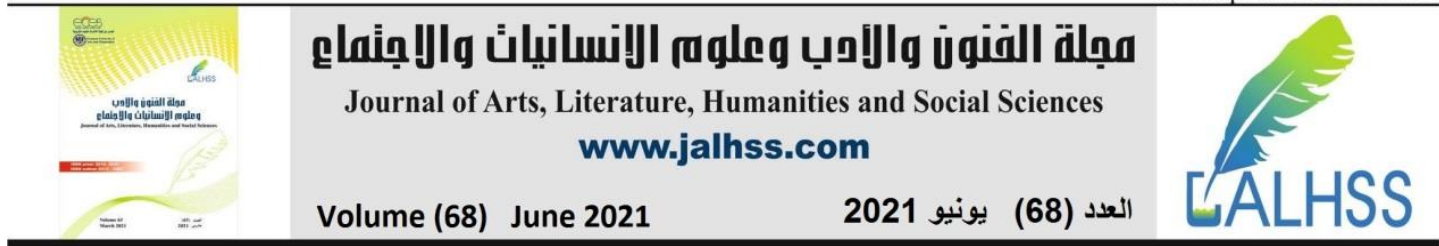

\section{التعليق على الار اسات السابقة}

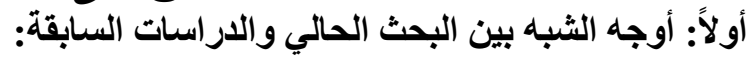

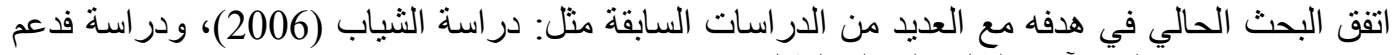

ومحمد (2013) في تناولها الآثار السلبية لعمالة الطفل. • اتفق البحث الحالي في هدفه مع العديد من الدراسات السابقة مثل: دراسة رزئ رزق الله (2013 (2015)، ودر اسة شهاب (2012)، ودر اسة كاظخ (2011) في التعرف في على أسباب عمالة الأطفال.

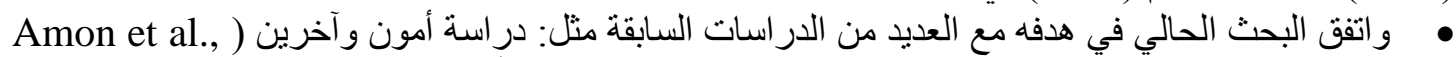
2012) في التعرف على دور منظمات حقوق الإنسان في الحد من عمل الإن الأطفال.

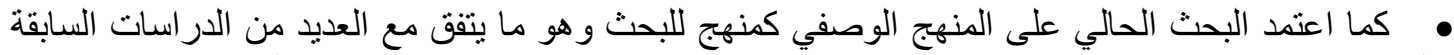

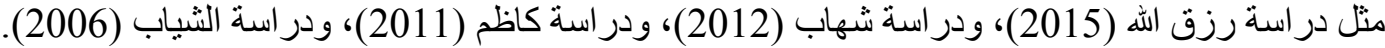

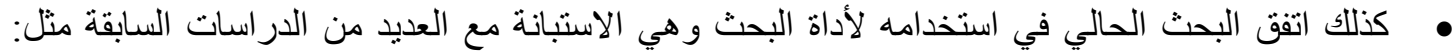

در اسة فدعم ومحمد (2013)، ودر اسة شهاب (2012)، ودر استة كاظم (2011)، ودر الاستة الثة الثياب (2006). • أما فيما ينعلق بعينة البحث، فقد اتفق البحث الحالي في اختياره العاملين في المنظمات التي تهتم بحقوق

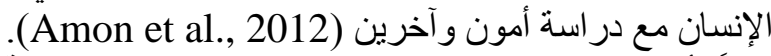

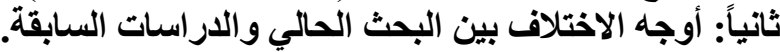

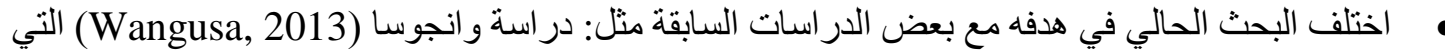

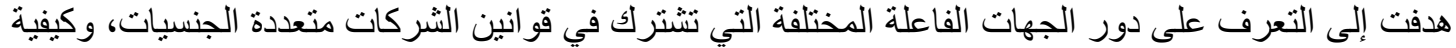
تحقيق المحتوى الموضو عي لأي أجندة تنظيمية.

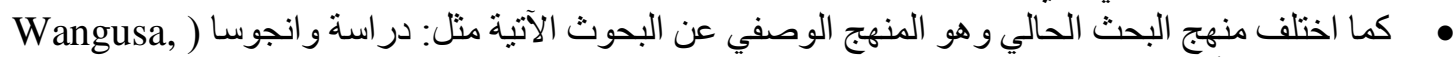
2013)، ودر اسة أمون و آخرين (Amon et al., 2012)، ودر اسة فدعم ومحمد (2013) التي استخدمت منهج المسح الاجتماعي بأسلوب المستح بالعينة.

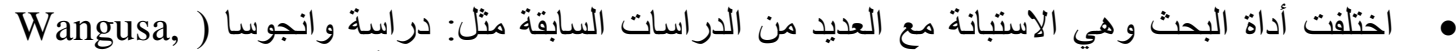

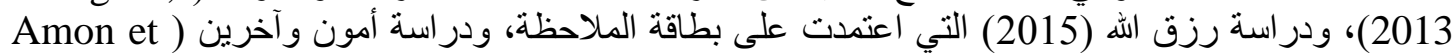

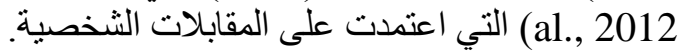

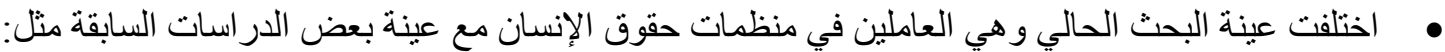

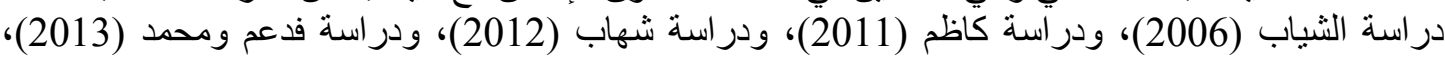
ودر اسة رزق الله (2015)، المكونة من الأطفال العاملين.

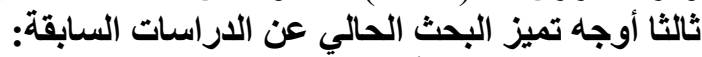

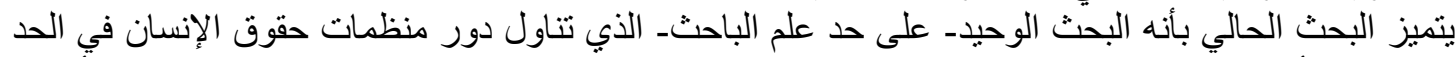

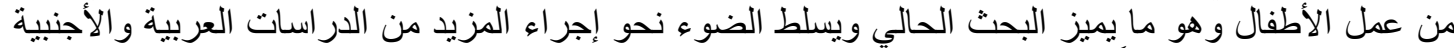

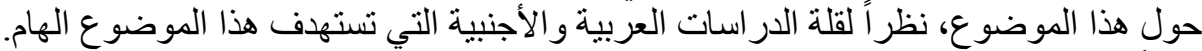
رابعاً: أوجه الاستفادة من الاراسات الطار السابقة: - ـ تدعيم الإطار النظري بنتائج دراسات وأبحاث حول دوات دور منظمات حقوق الإنسان في الحد من عمل الأطفال.

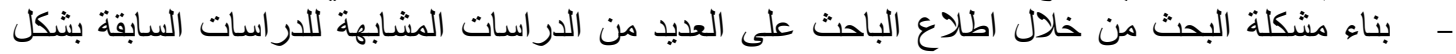

$$
\begin{aligned}
& \text { - ـ اختيار منهج البحث وبناء أداة البحث. } \\
& \text { - التعرف إلى نوع المعالجات الإحصائية المناسبة للبحث. }
\end{aligned}
$$

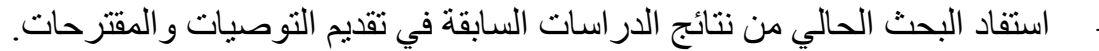

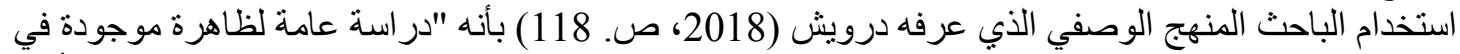

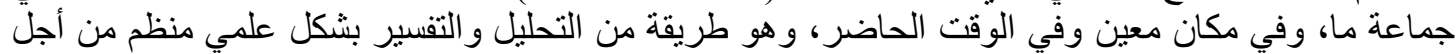
الوصول إلى أغر اض محددة لمشّكلة اجتماعية". 


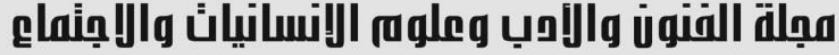

Journal of Arts, Literature, Humanities and Social Sciences

\section{www.jalhss.com}

Volume (68) June 2021

العدد (68) يونيو 2021

LALHSS

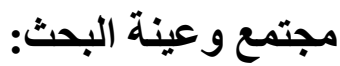

تكون مجتمع البحث من جميع العاملين بالجمعية الوطنية لحقوق الإنسان بالمملكة العربية السعودية، وقد اثتملت

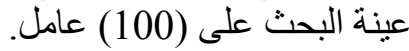
خصائص عينة البحث:

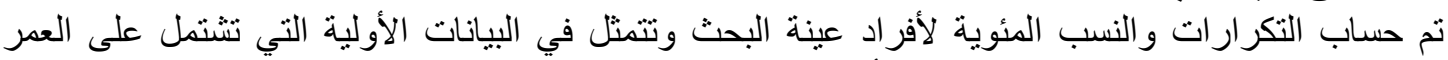

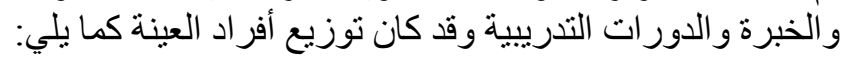
الجدول رقم (1) توزيع أفراد العينة حسب العمر

أـ توزيع أفراد العينة حسب العمر التور

\begin{tabular}{|c|c|c|}
\hline النسب المئوية & التكرارات & العمر \\
\hline$\% 56.0$ & 56 & أقل من 25 عام \\
\hline$\% 26.0$ & 26 & من 25 إلى45 عام \\
\hline$\% 18.0$ & 18 & أكثر من 45 عام \\
\hline $100 \%$ & 100 & الدرجة الكلية \\
\hline
\end{tabular}

الجدول رقم (2) توزيع أفراد العينة حسب الخبرة

\begin{tabular}{|c|c|c|}
\hline النسب المئوية & التكر ارات & الخبرة \\
\hline $68.0 \%$ & 68 & أقل من 5 سنو ات \\
\hline $23.0 \%$ & 23 & من 5-10 سنو ات \\
\hline $9.0 \%$ & 9 & أكثر من 10 سنة \\
\hline $100 \%$ & 100 & الدرجة الكلية \\
\hline
\end{tabular}

ج- توزيع أفراد العينة حسب علد الدورات التدريبية:

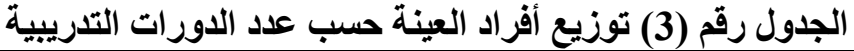

\begin{tabular}{|c|c|c|}
\hline النسب المئوية & التكر ار ات & عدد الدورات التدريبية \\
\hline $24.0 \%$ & 24 & لا يوجد \\
\hline $36.0 \%$ & 36 & دورة واحدة \\
\hline $27.0 \%$ & 27 & دورتين \\
\hline $13.0 \%$ & 13 & أكثر من دورتين \\
\hline $100 \%$ & 100 & الدرجة الكلية \\
\hline
\end{tabular}

وصف أداة البحث (الاستبانة):

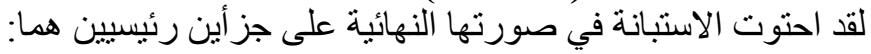

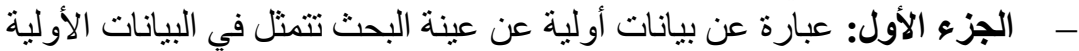

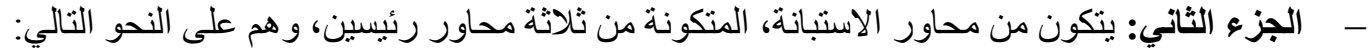

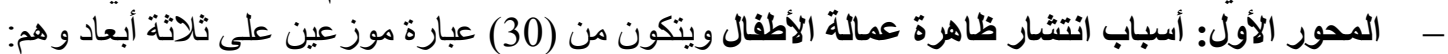

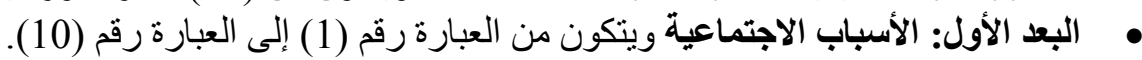

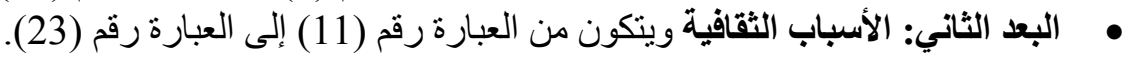

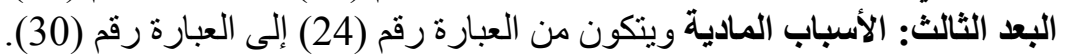

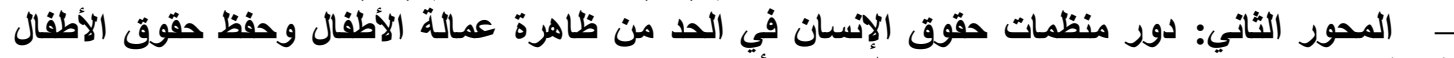

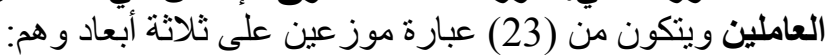

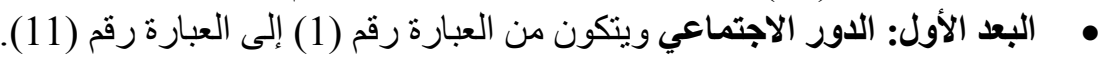

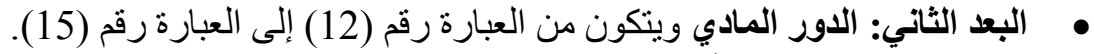

البعد الثالث: الدور الثقافي ويتكون من العبارة رقم (16) الإلى العبارة رقم (23). 


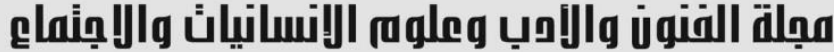

Journal of Arts, Literature, Humanities and Social Sciences www.jalhss.com

العدد (68) يونيو 2021

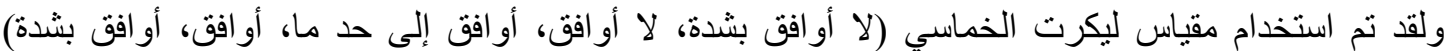
لتصحيح أداة البحث حيث تعطي الاستجابة لا أو افق بشدة (1)، لا أو أوافق (2)، أو افق إلى الى حد ما (3)، أو أفق أف (4)،

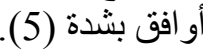

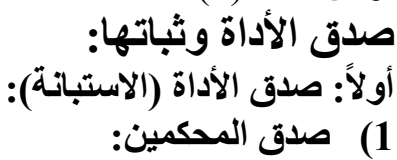

بعد الانتهاء من إعداد الاستبانة وبناء عبار اتها، و عرضها على مجموعة من المحكمين المختصين للتحقق من

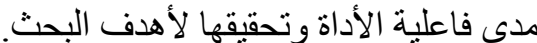

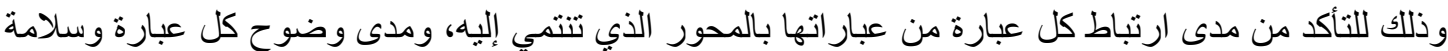

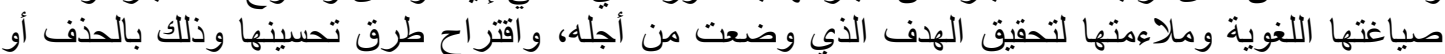

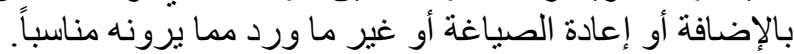

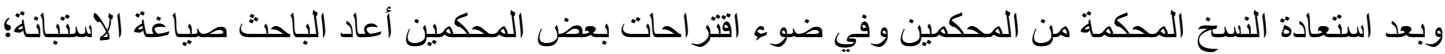

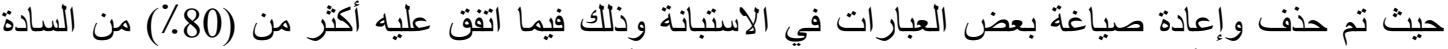

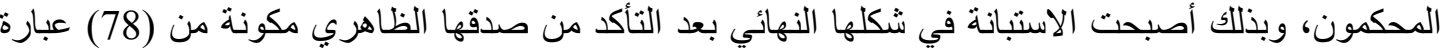

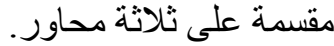
تم تطبيق أداة الدراسة على عينة اسنطلاعية مكونة من (30) مفردة للتأكد من صدقها وثباتها وذللك على النحو

2) صدق الاتساق الداخلي لمحاور الاستبانة:

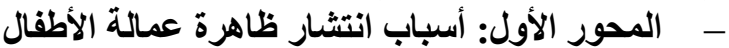

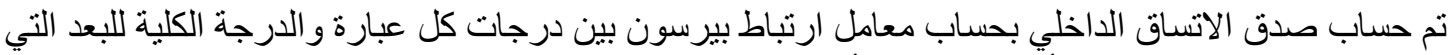

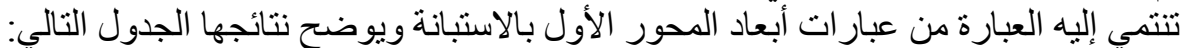
الجدول رقم (4) معاملات ارتباط بيرسون بين درجات كل عبارة والأرجة الإنة الكلية لكل بعد التي تنتمي إليه العبارة

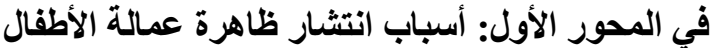

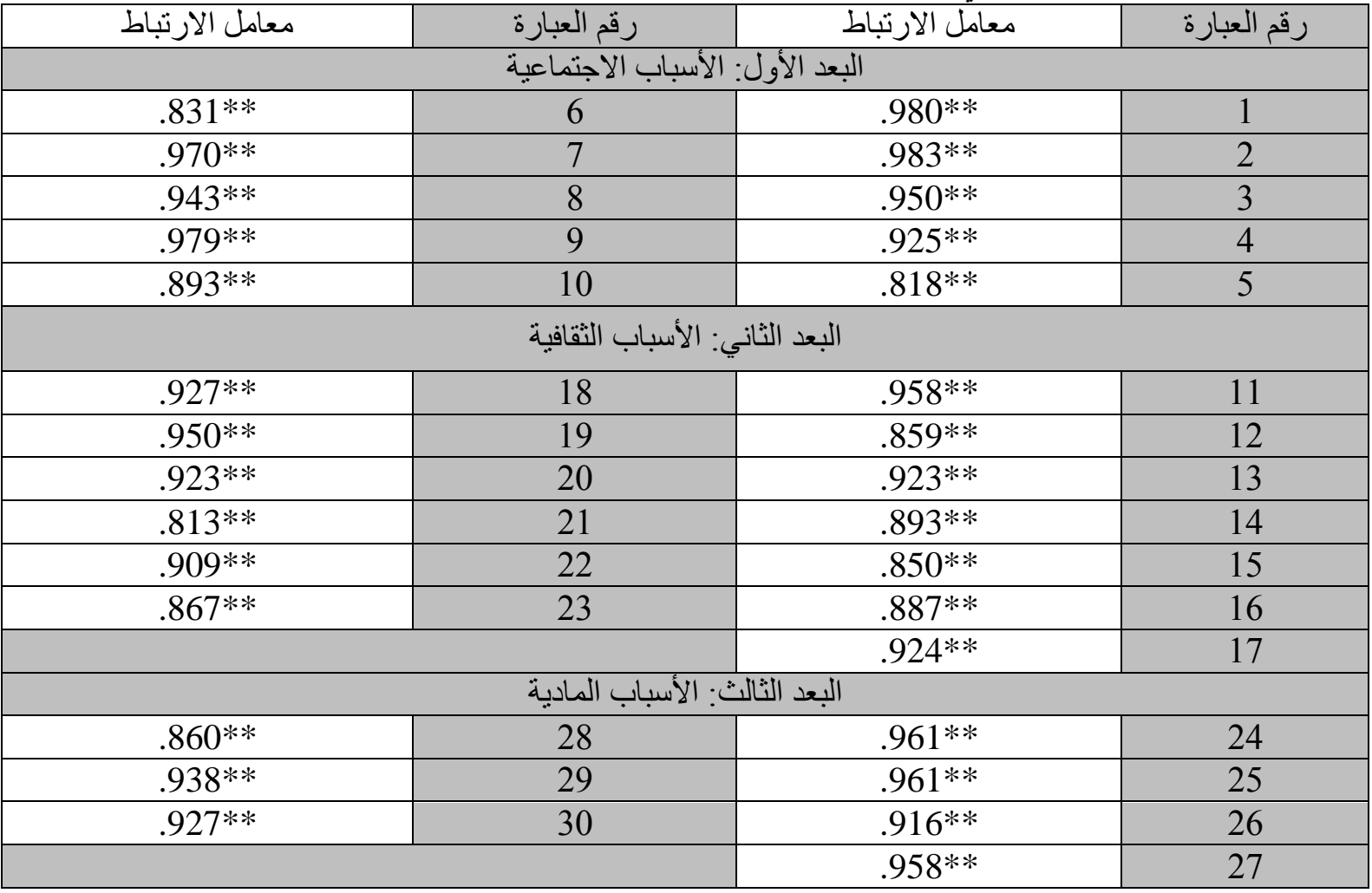




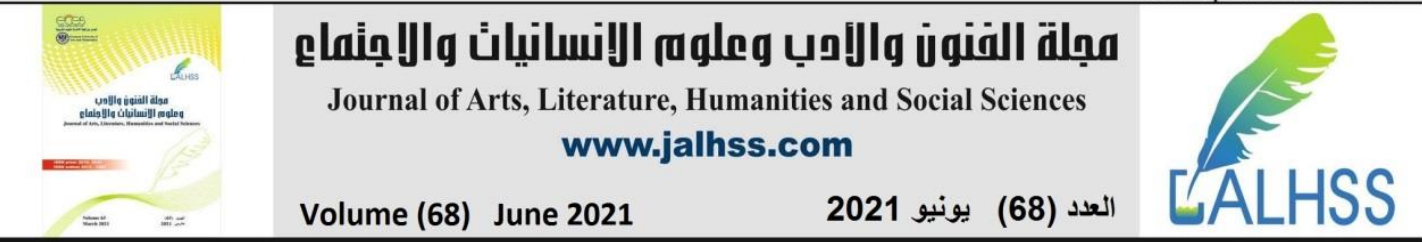

(0.01) (0.01).

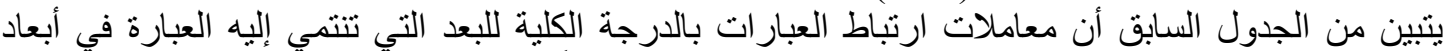

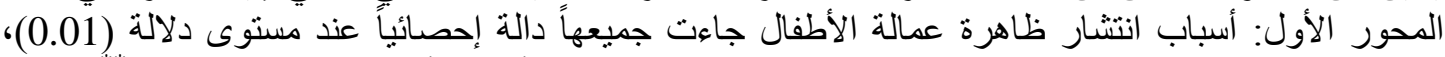

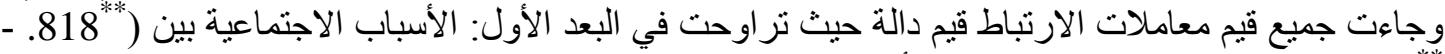

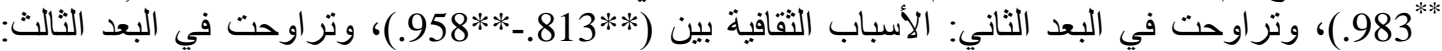

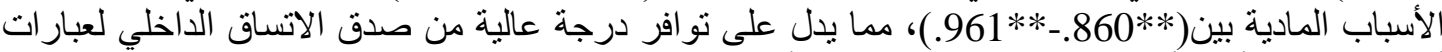

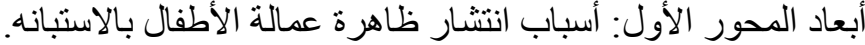

3 ) الصدق البنائي العام لأبعاد المحور الأول: أسباب النتشار ظاهرة الأبالئ عمالة الأطفال

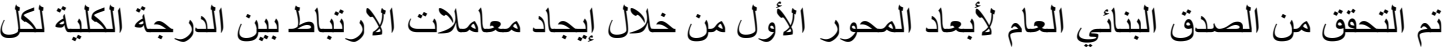

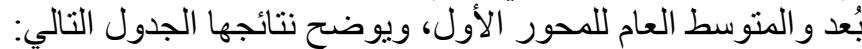

الجدول رقم (5) معاملات الارتباط بين الدرجة الكلية لكل بُعد والمتئ لألوسط العام للمحور الأول أسباب انتثار ظاهرة عمالة الأطفال

\begin{tabular}{|c|c|c|}
\hline معامل الارتباط & الأبعاد & ? \\
\hline $.958 * *$ & البعد الأول: الأسباب الاجتماعية & 1 \\
\hline $.966 * *$ & البعد الثاني: الأسباب الثقافية & 2 \\
\hline $.563 * *$ & البعد الثالث: الأسباب المادية & 3 \\
\hline
\end{tabular}

يتبين من الجدول السابق أن قيم معاملات الارتباط لأبعاد المحور الأول: أسباب انتشار ظاهرة عمالة الأطفال و المتوسط العام للمحور الأول بالاستبانة جاءت بقيم عالية حيث تراوحت بئ بين (203.

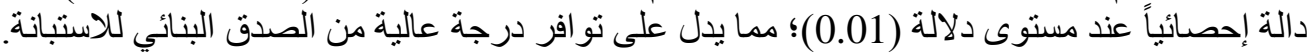

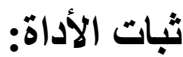
1

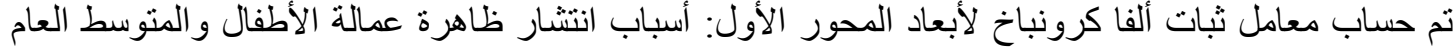

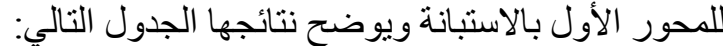

الجدول رقم (6) معامل ثبات ألفا كرونباخ لأبعاد المحور الأول والمتوسط العام للمحور الأول بالاستبانة

\begin{tabular}{|c|c|c|c|}
\hline كرونباخ ألفا & عدد العبار ات & الأبعاد & 5 \\
\hline .823 & 10 & البعد الأول: الأسباب الاجتماعية & 1 \\
\hline .816 & 13 & البعد الثاني: الاسباب الثقافية & 2 \\
\hline .986 & 7 & البعد الثالث: الأسباب المادية & 3 \\
\hline .893 & 30 & المتوسط العام & \\
\hline
\end{tabular}

يتبين من الجدول السابق أن قيم معاملات الثبات لأبعاد المحور الأول: أسباب انتشار ظاهرة عمالة الأطفال

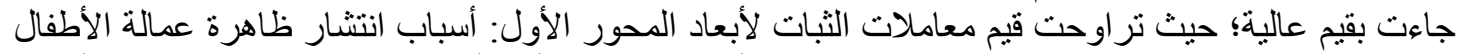

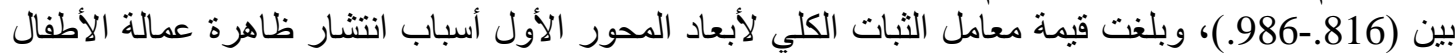

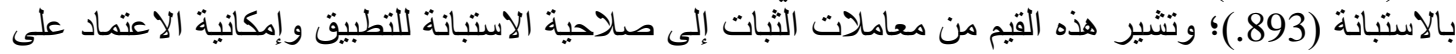
نتائجها و الوثوق بها. • المحور الثاني: دور منظمات حقوق الإنسان في الحد من ظاهرة عمالة الأطفال وحفظ حقوق الأطفال

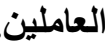

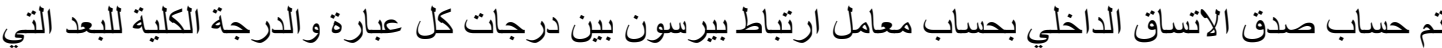

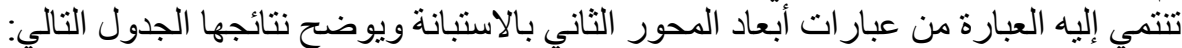




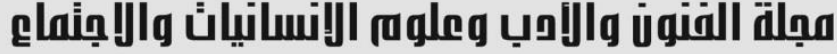

Journal of Arts, Literature, Humanities and Social Sciences www.jalhss.com

الجدول رقم (7) معاملات ارتباط بيرسون بين درجات كل عبارة والارجة الكلية لكل بعد التي تتنمي إليه العبارة في المحور الثاني: دور منظمات حقوق الإنسان في الحد من ظاهرة عمالة الأطفال وحفظ حقوق الأل الأطفال العاملين في اندين

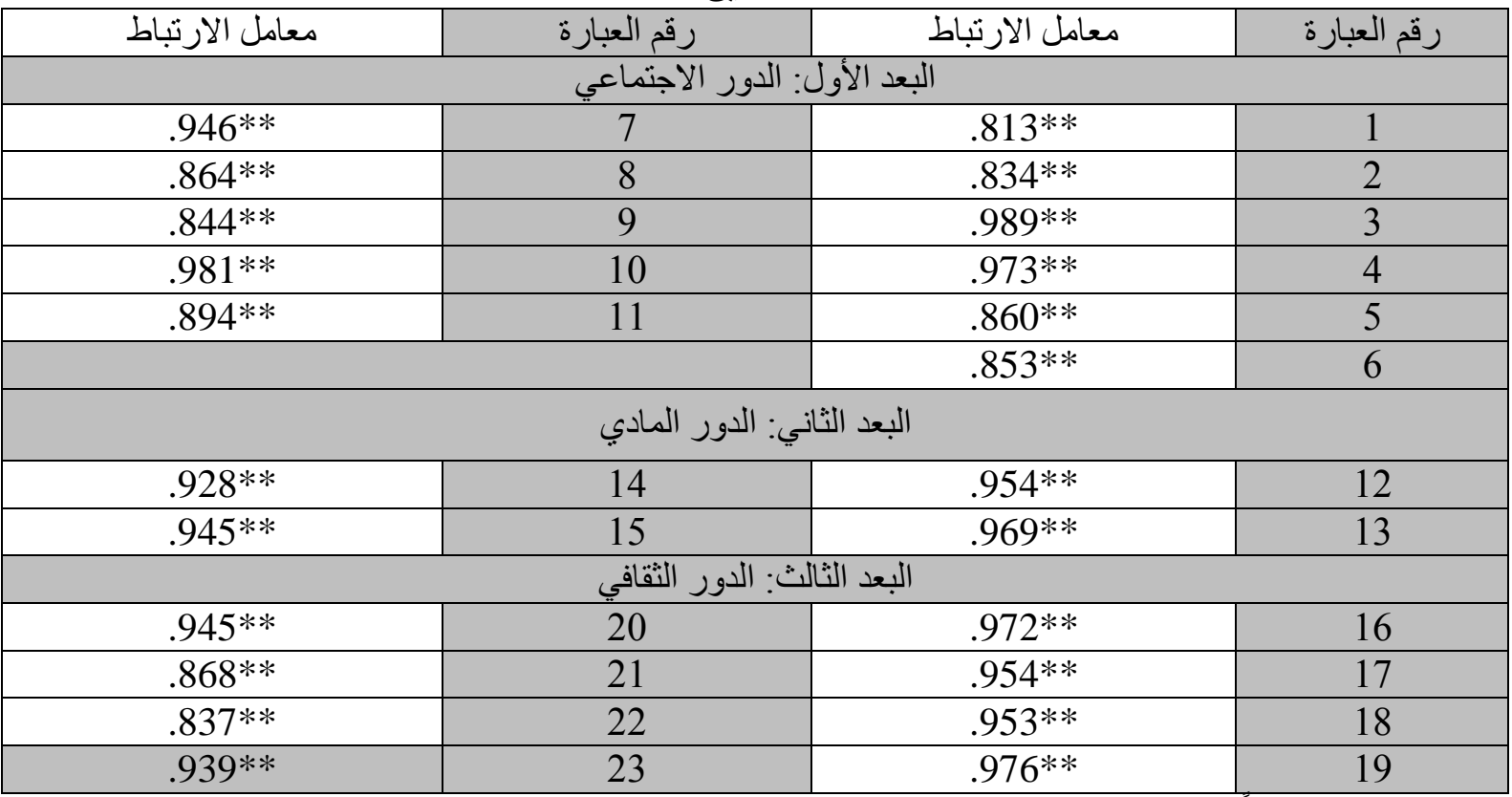

** دال إحصائياً عند مستوى الدلالة (0.01).

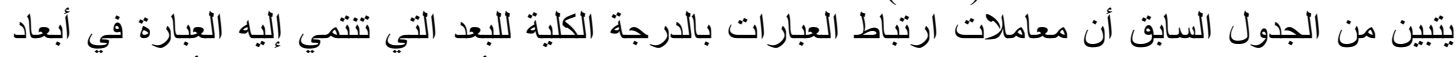

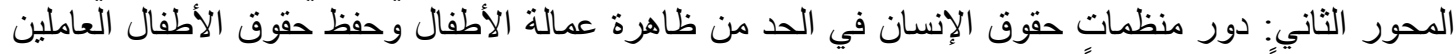

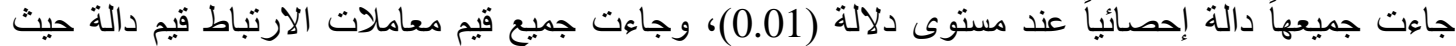

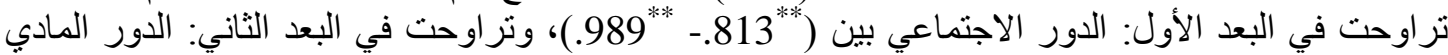

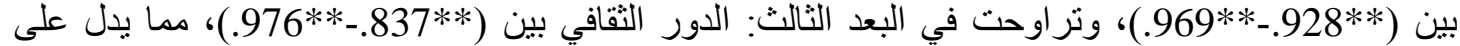
تو افر درجة عالية من صدق الاتساق الداخلي لعبار ات أبعاد المحور الثانياني: دور منظمات حقوق الإنات الإنسان في الحد

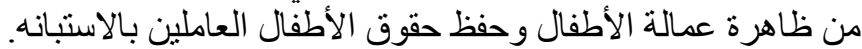

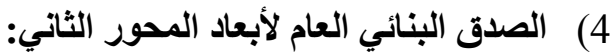

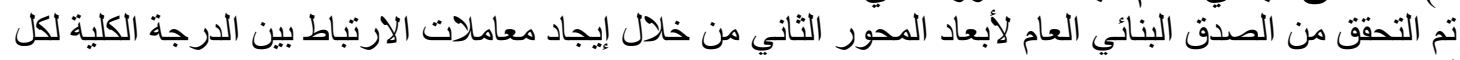

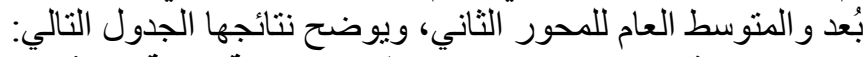

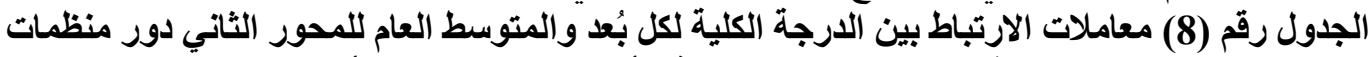
حقوق الإنسان في الحد من ظاهرة عمالة الأطفال وحفظ حقوق الأبط الأطفال العاملين

\begin{tabular}{|c|c|c|}
\hline معامل الارتباط & الأبعاد & 5 \\
\hline $.992 * *$ & البعد الأول: الدور الاجتماعي & 1 \\
\hline $.980 * *$ & البعد الثاني: الدور المادي & 2 \\
\hline $.985 * *$ & البعد الثالث: الدور الثقافي & 3 \\
\hline
\end{tabular}

يتبين من الجدول السابق أن قيم معاملات الارتباط لأبعاد المحور الثاني: دور منظمات حقوق الإنسان في الحد الإند

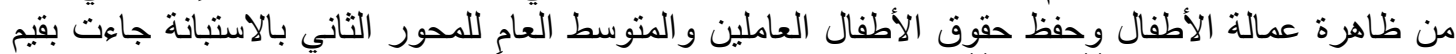

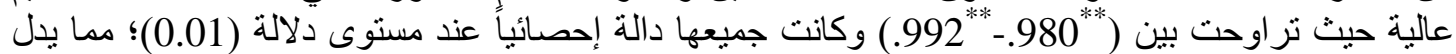
على نو افر درجة عالية من الصدق البنائي للاستبانة. 


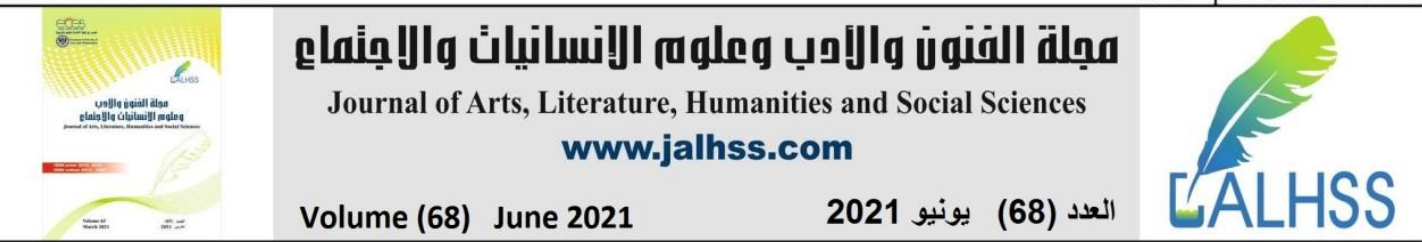

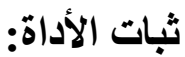

2) ألفا كرونباخ لأبعاد المحور الثاني: دور منظمات حقوق الإنسان في الحد من ظاهرة عمالة الأطفال وحفظ

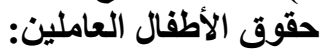

تم حساب معامل ثبات ألفا كرونباخ لأبعاد المحور الثاني: دور منظمات حقوق الإنسان في الحد من ظاهرة عمالة

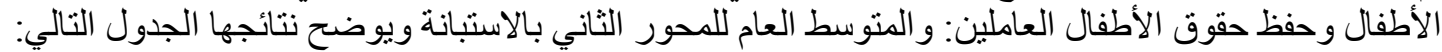
الجدول رقم (9) معامل ثبات ألفا كرونباخ لأبعاد المحور الثاني والمتوسط العادئ العام للمحور الثاني بالاستبانة

\begin{tabular}{|c|c|c|c|}
\hline كرونباخ ألفا & عدد العبار ات & الأبعاد & r \\
\hline .989 & 11 & البعد الأول: الدور الاجتماعي & 1 \\
\hline .993 & 4 & البعد الثاني: الدور المادي & 2 \\
\hline .991 & 8 & البعد الثالث: الدور الثقافي & 3 \\
\hline .992 & 23 & المتوسط العام & \\
\hline
\end{tabular}

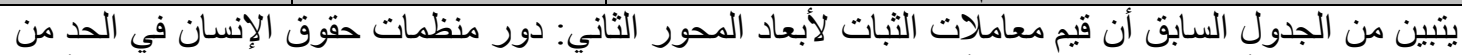

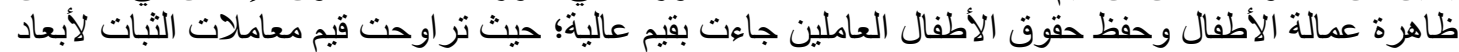

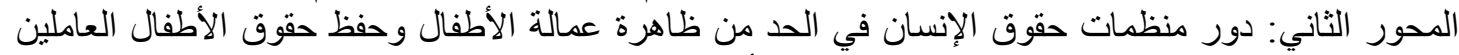

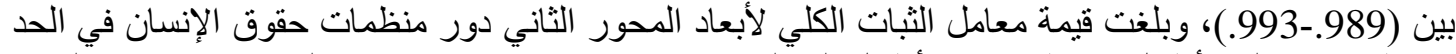

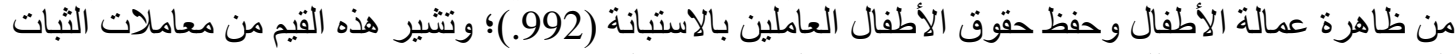

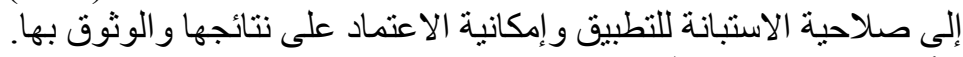
الأساليب الإحصائية:

بناء على طبيعة البحث و الأهداف التي سعي الباحث إلى تحقيقها، تم تحليل البيانات باستخدام برنامج الحزمة الإحصائية للعلوم الاجتماعية (spss) واستخر اج النتائج والئ وفقاً للأساليب الإحصائية التالية:

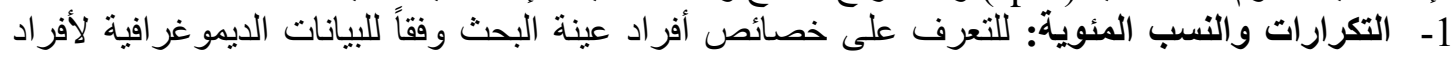

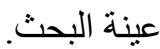
2- المتوسطات الحسابية والانحرافات المعيارية: لحساب منوسطات عبارات الاستبيان وكذلك الدرجات الكلية

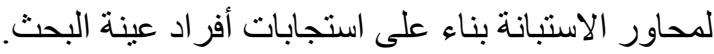

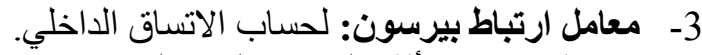

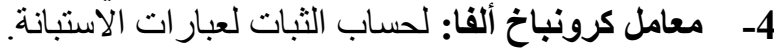

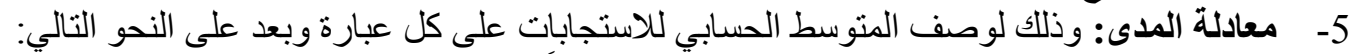

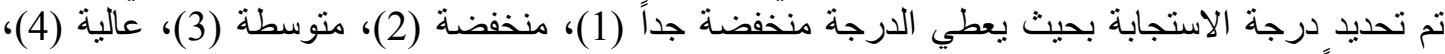

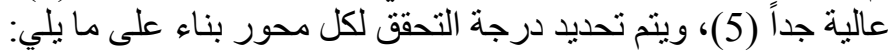

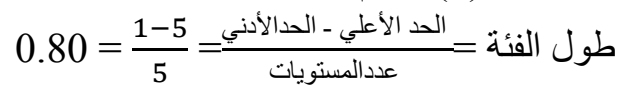

من 1 إلى أقل من 1.80 نمثل درجة استجابة (منخفضة جداً). من 1.80 إلى أقل من 2.60 إلى 2.60 تمثل درجة استجابة (منخفضة).

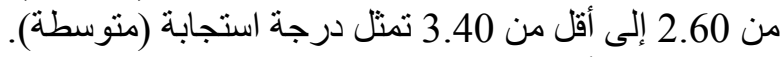
من 3.40 إلى أقل من 4.20 من 4.20 تمثل درجة استجابة (عالية). من 4.20 إلى أقل من 5 تمثل درجة استجابة (عالية جداً).

\section{عرض ومناقثة وتفسير نتائج تساؤلات الاراسة:}

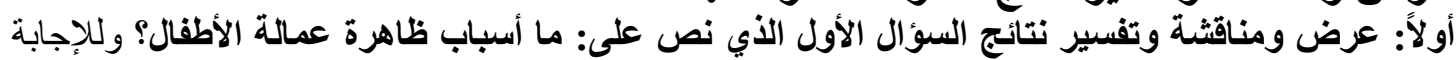

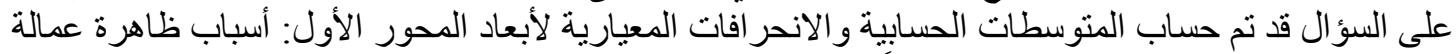
الأطفال، ومن ثم ترتيب هذه الأبعاد تنازلياً حسب المتوسط الحسابي لكل بعد، وييين ذللك الجدول رقم (10) 


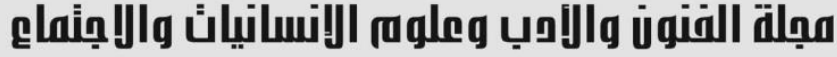

Journal of Arts, Literature, Humanities and Social Sciences www.jalhss.com

Volume (68) June 2021

العدد (68) يونيو 2021

LALHSS

الجدول رقم (10) المتوسطات الحسابية والانحرافات المعيارية لأبعاد المحور الأول: أسباب ظاهرة عمالة

الأطفال

\begin{tabular}{|c|c|c|c|c|c|}
\hline 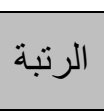 & استجابة & الانحر افياري & الحسابي & أبعاد المحور الأول & الرقم \\
\hline 3 & عالية & 1.338 & 3.74 & البعد الأول: الأسباب الاجتماعية & 1 \\
\hline 2 & عالية & 1.175 & 3.83 & البعد الثاني: الأسباب الثقافية & 2 \\
\hline 1 & عالية & 1.192 & 3.90 & البعد الثالث: الأسباب المادية & 3 \\
\hline-- & عالية & 1.150 & 3.81 & المتوسط العام & \\
\hline
\end{tabular}

يتبين من الجدول السابق: أن المنوسط العام للمحور الأول: أسباب ظاهرة عمالة الأطفال، قد جاء بدرجة استجابة

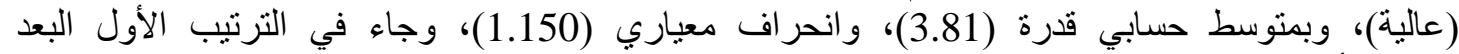

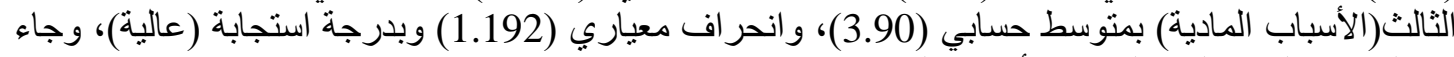

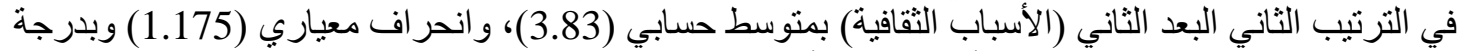
استجابة (عالية)، ويليه في الترتيب الأخير البعد الأول (الآسباب الاجتماعية) بمتوسط حسابي (33.83)، (3.74)، وانحر افي معياري (1.338) وبدرجة استجابة (عالية).

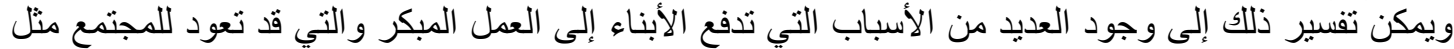

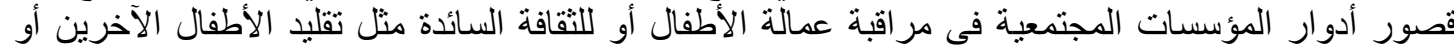
الاحتياجات المالية للطفل و الأسرة.

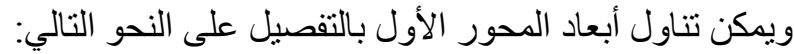

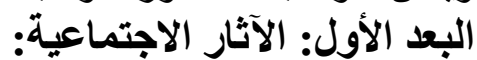

الجدول رقم (11) التكرارات والنسب الأبـات المئوية والمتوسطات الحسابية والانحر افات المعيارية لاستجابات أفراد العينة للبعد الأول: الآثار الاجتماعية العابية

\begin{tabular}{|c|c|c|c|c|c|}
\hline | درجة الاستجابة & الترتيب & الإنحر اف & الحستبي & 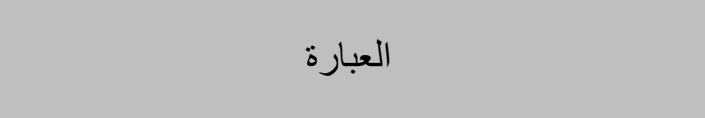 & s \\
\hline عالية & 8 & 1.423 & 3.71 & ضعف الدور الرقابي لمؤسسات الرعاية الاجتماعية. & 1 \\
\hline عالية & 6 & 1.429 & 3.72 & ارتفاع نسبة البطالة بين الر اشدين. & 2 \\
\hline عالية & 4 & 1.404 & 3.74 & التفكلك الأسري الذي يعيش فيه الطفل. & 3 \\
\hline عالية & 7 & 1.409 & 3.71 & هروب الأطفال من المدرسة. & 4 \\
\hline 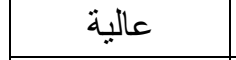 & 5 & 1.399 & 3.73 & وجود أطفال بدون اسر تحميهح وتر عاهم. & 5 \\
\hline عالية & 2 & 1.373 & 3.79 & الهجرة من الريف إلى المدينة. & 6 \\
\hline عالية & 1 & 1.383 & 3.84 & عدم اهتمام منظمات المجتمع المدني بمتابعة الأطفال. & 7 \\
\hline عالية & 9 & 1.419 & 3.69 & ضعف التو اصل بين البيت و المدرسة. & 8 \\
\hline عالية & 10 & 1.378 & 3.67 & الطلاق بين الأبوين. & 9 \\
\hline عالية & 3 & 1.386 & 3.76 & فقدان الو الدين أو أحدهما. & 10 \\
\hline عالية & -- & 1.338 & 3.74 & المتوسط العام & \\
\hline
\end{tabular}

يتبين من الجدول السابق: أن المنوسط العام للبعد الأول: الأسباب الاجتماعية جاء بدرجة استجابة (3.74)، وبمتوسط حسابي قدرة (1.338)، و انحر افت الفيط معياري (عالية). ويمكن تفسير مجيء البعد الأول: الأسباب الاجتماعية بدرجة استجابة الابة (عالية)، إلى أنه تعد الأسباب الاجتماعية

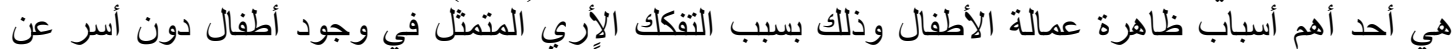




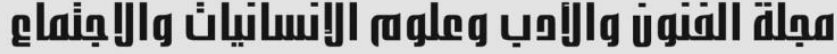

Journal of Arts, Literature, Humanities and Social Sciences www.jalhss.com

طريق فقدان الوالدين أو أحداً منهم، وضعف التواصل بين البيت و المدرسة أو حدوث انفصال بين الوالدين،

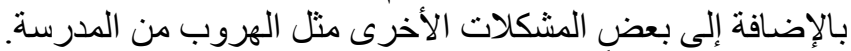

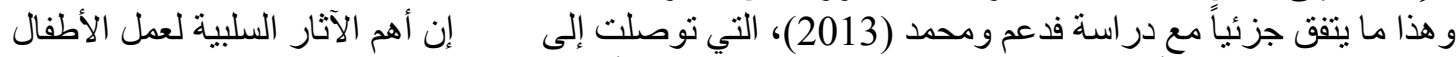

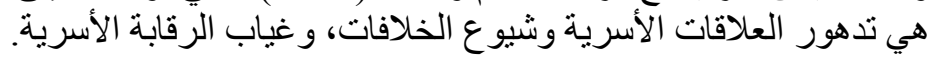

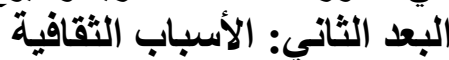
الجدول رقق (12) التكرارات والنسب المئوية والمتوسطات الحسابية والانحر افات المعيارية لاستجابات أفراد العينة للبعد الثاني: الأسباب الثقافية الثبانة

\begin{tabular}{|c|c|c|c|c|c|}
\hline | درجة الاستجابة & الترتيب & الانحر اف & الحسابي & 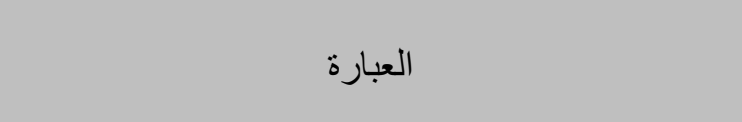 & 5 \\
\hline عالية & 9 & 1.371 & 3.80 & تدني مستوى تعليم الأبوين وو عيهم بحقوق وحاجات & 11 \\
\hline عالية & 10 & 1.380 & 3.79 & انتشار العنف الأسري. & 12 \\
\hline عالية & 4 & 1.343 & 3.88 & رغبة الأهل الثديدة في العمل. & 13 \\
\hline عالية & 6 & 1.366 & 3.85 & العنف ضد التلاميذ. & 14 \\
\hline عالية & 11 & 1.424 & 3.75 & الور اثثة المهنية (تعلم الطفل مهنة أبيه). & 15 \\
\hline 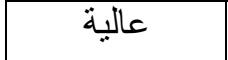 & 5 & 1.385 & 3.86 & اعتقاد الأهل بان عمل الطفل جز ء من تنشئتَه الاجتماعية. & 16 \\
\hline 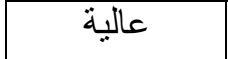 & 2 & 1.269 & 3.92 & ضعف الإرشاد و التوجيه. & 17 \\
\hline عالية & 13 & 1.443 & 3.67 & تقليد الآخرين من الأطفال. & 18 \\
\hline عالية & 7 & 1.361 & 3.84 & ضعف الإرشـاد و التوجيه. & 19 \\
\hline عالية & 1 & 1.227 & 3.99 & عدم انتقاء الأسرة لأصدقاء أبنائهم. & 20 \\
\hline عالية & 12 & 1.413 & 3.68 & ضعف الوازع الديني لدى الآباء. & 21 \\
\hline عالية & 3 & 1.303 & 3.91 & كثرة عدد الأبناء في العائلة الواحدة. & 22 \\
\hline عالية & 8 & 1.359 & 3.82 & زواج أحد الأُبوين بآخر. & 23 \\
\hline عالية & -- & 1.175 & 3.83 & المتوسط العام & \\
\hline
\end{tabular}

ينتبين من الجدول السابق: أن المنوسط العام للبعد الثناني: الأسباب الثقافية جاء بدرجة استجابة (عالية)، وبمتوسط

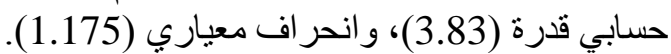

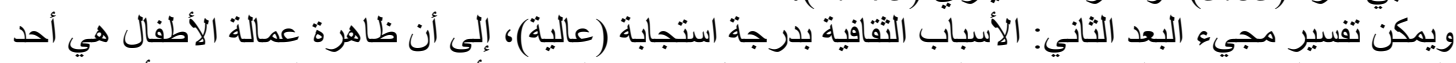

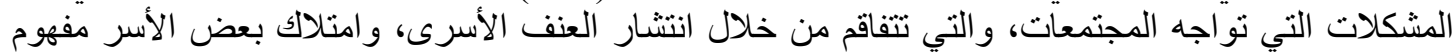

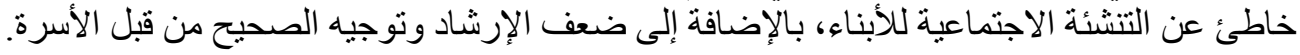




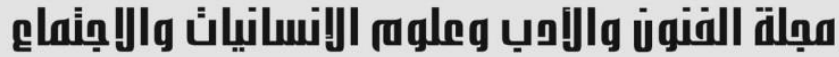 \\ Journal of Arts, Literature, Humanities and Social Sciences www.jalhss.com}

العدد (68) يونيو 2021

LALHSS

البعد الثالث: الأسباب المادية

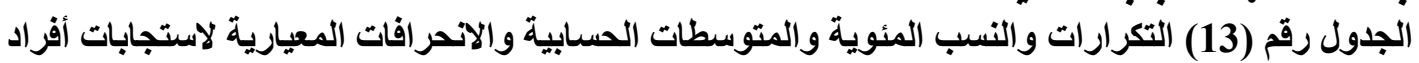
العينة للبعد الثالث: الأسباب المادية

\begin{tabular}{|c|c|c|c|c|c|}
\hline | درجة الاستجابة & الترتيب & الانحر اف & الحسابي & 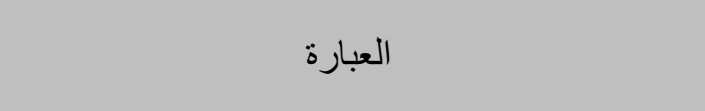 & r \\
\hline عالية & 3 & 1.323 & 3.92 & انخفاض مستوى دخل الأسرة & 24 \\
\hline عالية & 7 & 1.306 & 3.85 & كبر حجم الأسرة & 25 \\
\hline عالية & 4 & 1.311 & 3.91 & التحو لات الاقتصادية العميقة والجذرية التي حدثت في & 26 \\
\hline 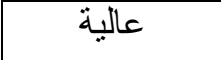 & 6 & 1.333 & 3.86 & حاجة الطفل للمال لشر اء بعض احتياجاته & 27 \\
\hline 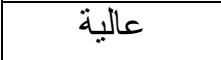 & 1 & 1.258 & 3.95 & غلاء المعيشة وارتفاع الأسعار & 28 \\
\hline عالية & 5 & 1.314 & 3.90 & غياب الأب المتكرر عن الأسرة & 29 \\
\hline عالية & 2 & 1.265 & 3.93 & ارتفاع بدلات الإيجار للاور السكنية & 30 \\
\hline عالية & -- & 1.192 & 3.90 & المتوسط العام & \\
\hline
\end{tabular}

يتبين من الجدول السابق: أن المتوسط العام للبعد الثالث: الأسباب المادية جاء بدرجة استجابة (عالية)، وبمتوسط حسابي قدرة (3.90)، و وانحر اف معياري الفئ (1.192).

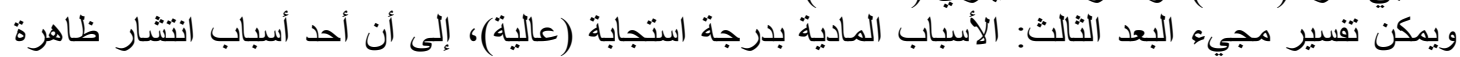

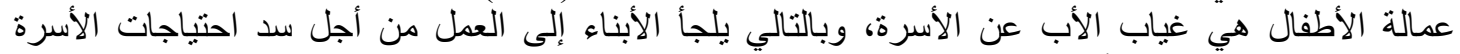
ومواجهة الغلاء و أرتفاع الأسعار.

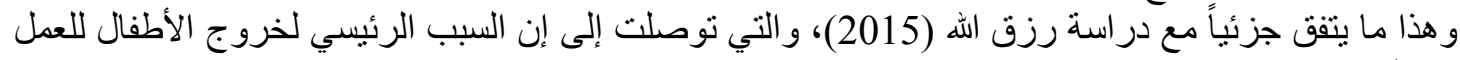
هو الفقر. و هذا ما يتفق أيضًا مع دراسة كاظم (2011)، التي توصلت إلى إن أهم أسباب عمالة الأطفال هي انخفاض التفاض

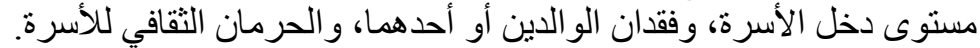

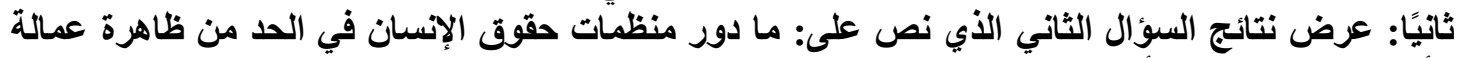
الأطفال وحفظ حقوق الأطفال العأملين؟

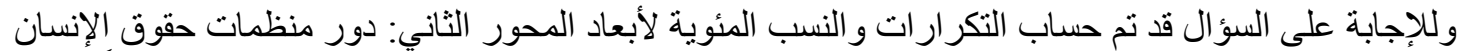

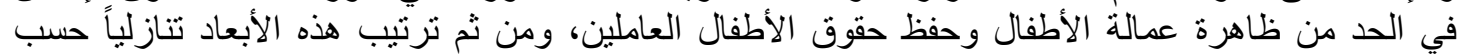

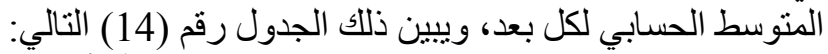

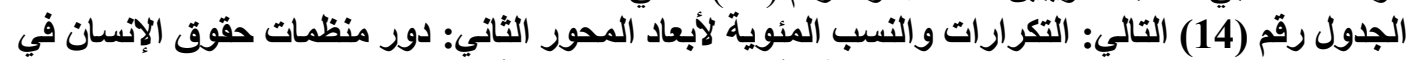

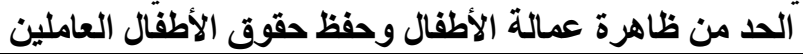

\begin{tabular}{|c|c|c|c|c|c|}
\hline 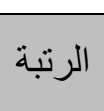 & استجابة & الانحرياري & الحستوسي & إبعاد المحور الثاني & 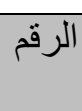 \\
\hline 2 & متوسطة & .796 & 3.08 & البعد الأول: الدور الاجتماعي & 1 \\
\hline 1 & متوسطة & .823 & 3.27 & البعد الثاني: الدور المادي & 2 \\
\hline 3 & متوسطة & .853 & 3.05 & البعد الثالث: الدور الثقافي & 3 \\
\hline-- & متوسطة & .627 & 3.10 & المتوسط العام & \\
\hline
\end{tabular}

يتبين من الجدول السابق: أن المتوسط العام للمحور الثاني: دور منظمات حقوق الإنسان في الحد من ظاهرة

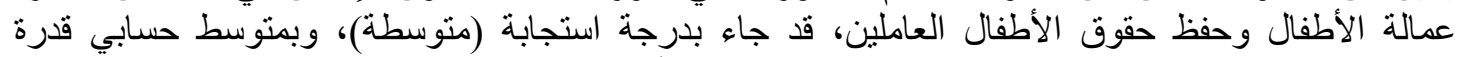

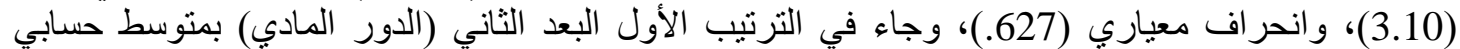
(3.27)، و انحر اف معياري (823.) وبدرجة استجابة (منوسطة)، وجاء في الترتيب الثاني البعد الأول (الدور 


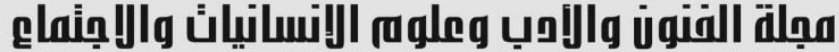

Journal of Arts, Literature, Humanities and Social Sciences www.jalhss.com

الاجتماعي) بمتوسط حسابي (3.08)، و انحر اف معياري (396.7. وبدرجة استجابة (متوسطة)، ويليه في الترتيب الأخير البعد الثالث (الدور الثقافي) بمتوسط حسابي (3.05)، وانحراف معياري (853.) وبندة) وبدرجة استجابة

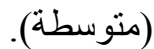
ويمكن عزو ذللك إلى أنه على الرغم من أهمية قضية عمالة الأطفال إلا أن دور منظمات حقوق الإنسان لم بأت

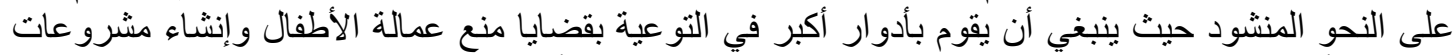

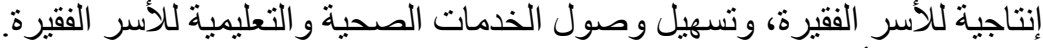
ويمكن تناول أبعاد المحور بمزيد من التفصيل على التصني النحو التالي:

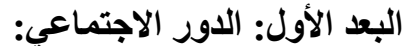
الجدول رقم (15) التكرارات والنسب المئوية والمتوسطات الحسابية والاتحرافات المعيارية لاستجابات أفراد العينة للبعد الأول: الاور الاجتماعي

\begin{tabular}{|c|c|c|c|c|c|}
\hline درجة الاستجابة & الترتيب & 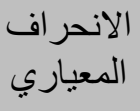 & 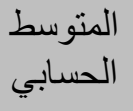 & 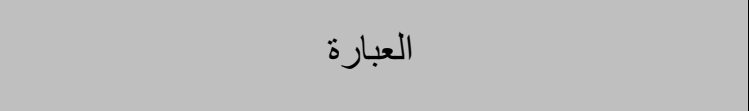 & s \\
\hline متوسطة & 8 & 1.310 & 3.04 & المشاركة الفعالة في تنظيم حملات تو عيه لدعم قضية & 1 \\
\hline منوسطة & 11 & 1.355 & 2.94 & استصدار بعض القرار ات بتفعيل دور اللجان الاستشارية & 2 \\
\hline منوسطة & 10 & 1.092 & 2.98 & الإسر اع بتكوين اتحاد نو عي من الجمعيات المعنية & 3 \\
\hline متوسطة & 2 & 1.195 & 3.19 & بذل أهية قصوى بقضية عمالة الأطفال باستنفار الجهات & 4 \\
\hline متوسطة & 6 & 1.269 & 3.08 & إيجاد آلية لضبط المخالفات. & 5 \\
\hline متوسطة & 3 & 1.443 & 3.17 & 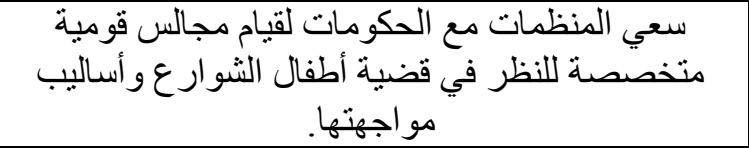 & 6 \\
\hline متوسطة & 9 & 1.363 & 3.02 & اتخاذ كافة التدابير لحماية حقوق الطفل وتحسين & 7 \\
\hline منوسطة & 4 & 1.385 & 3.11 & اتخاذ كافة التدابير لضمان حصوليت وحمايتهم من العنفي المأوي و الغذاء & 8 \\
\hline متوسطة & 7 & 1.391 & 3.06 & ضرورة حثاية الأطفال من المنع على الاستغلال في سوقة في تكوين فرق. & 9 \\
\hline متوسطة & 5 & 1.102 & 3.09 & 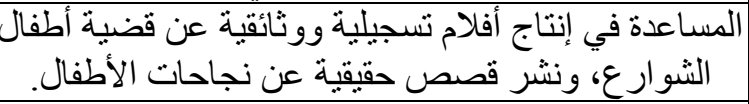 & 10 \\
\hline متوسطة & 1 & 1.313 & 3.21 & و إنر الك فنانين ورياضيين ومثقفين في التو عية بقضية & 11 \\
\hline متوسطة & -- & .796 & 3.08 & المتوسط العام & \\
\hline
\end{tabular}




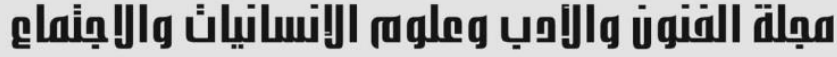

Journal of Arts, Literature, Humanities and Social Sciences www.jalhss.com

يتبين من الجدول السابق: أن المتوسط العام للبعد الأول: الدور الاجتماعي جاء بدرجة استجابة (متوسطة)،

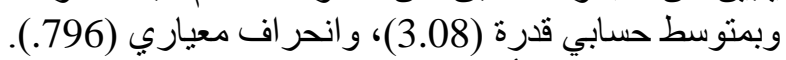

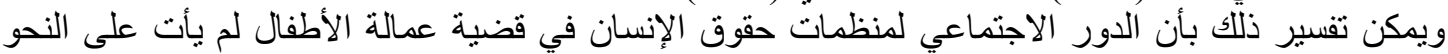

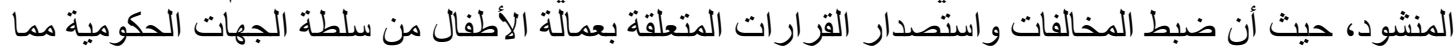
يحول دون تدخل منظمات حقوق الإنسان بها على نحو فلى فعال.

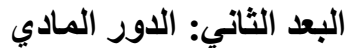

الجدول رققم (16) التكرأرات والنسب المئوية والمتوسطات الحسابية والانحر افات المعيارية لاستجابات أفراد العينة للبعد الثاني: الدور المادي المئي

\begin{tabular}{|c|c|c|c|c|c|}
\hline | درجة الاستجابة & الترتيب & 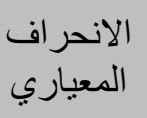 & 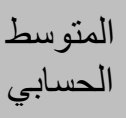 & 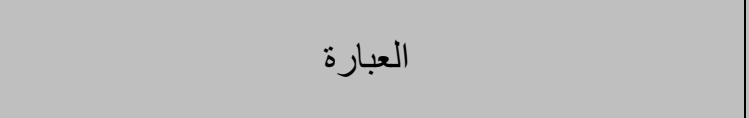 & r \\
\hline 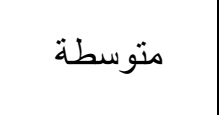 & 3 & 1.018 & 3.29 & 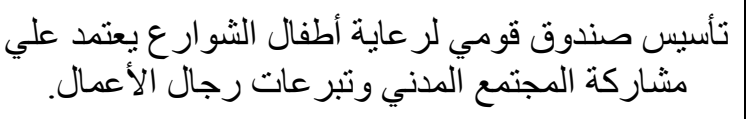 & 12 \\
\hline متوسطة & 1 & 1.020 & 3.36 & توفير ضمانات الثفافية في التعامل مع أمو ال الصندوق. & 13 \\
\hline منوسطة & 2 & .989 & 3.35 & إنشاء مشرو عات إنتاجية لتوفير فرص عمل خاصة & 14 \\
\hline 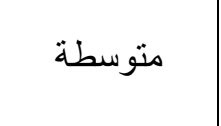 & 4 & 1.070 & 3.08 & 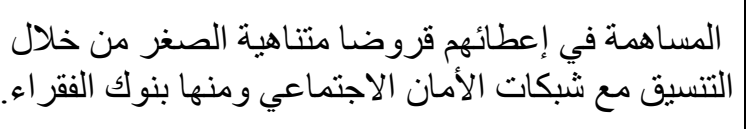 & 15 \\
\hline متوسطة & -- & .823 & 3.27 & المتوسط العام & \\
\hline
\end{tabular}

ينبين من الجدول السابق: أن المنوسط العام للبعد الثاني: الدور المادي جاء بدرجة استجابة (متوسطة)، وبمتوسط

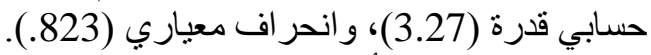

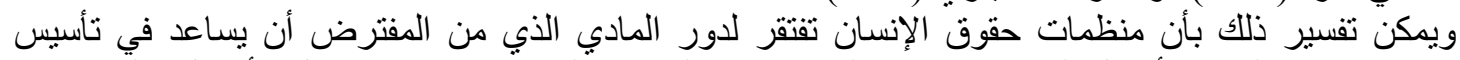

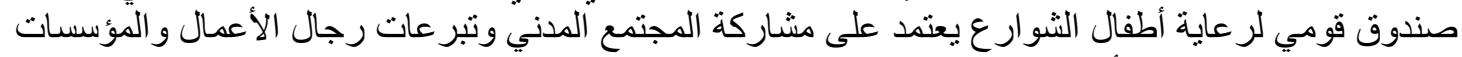

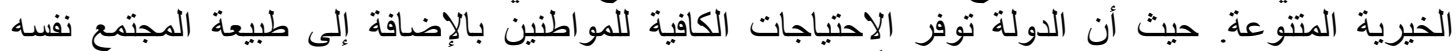
و الجمعيات الأهلية التي تدعم تللك الفئات مادياً.

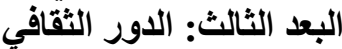

الجدول رقم (17) التكرارات والنسب المئوية والمتوسطات الحسابية والانحر افات المعيارية لاستجابات أفراد العينة للبعد الثالث: الاور الثقافي الثية

\begin{tabular}{|c|c|c|c|c|c|}
\hline درجة الاستجابة & الترتيب & المعياري اف & الحسابي & العبارة & 5 \\
\hline متوسطة & 8 & 1.004 & 2.73 & تو عية الأطفال العاملين و أسر هم و أصحاب العمل بقانون & 16 \\
\hline
\end{tabular}




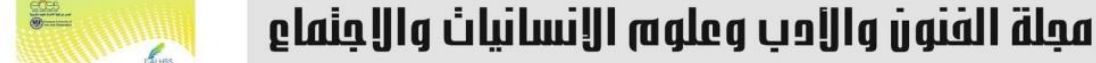

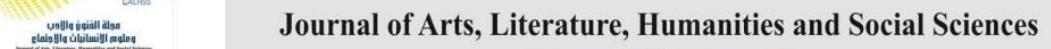

www.jalhss.com

العدد (68) يونيو 2021

AALHSS

\begin{tabular}{|c|c|c|c|c|c|}
\hline | درجة الاستجابة & الترتيب & 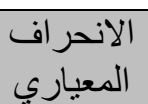 & 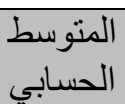 & 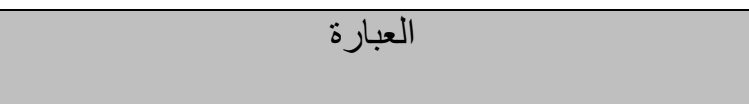 & r \\
\hline & & & & حماية الطفل بهدف تمكينهم من الدفاع عن حقوقهم. & \\
\hline متوسطة & 5 & 1.063 & 3.04 & الاهتمام بالنساء و الأطفال في خطط التنمية الاقتصادية & 17 \\
\hline متوسطة & 6 & 1.049 & 2.99 & وضع آليات وبر امج للوقاية و المكافحة اللازمة. & 18 \\
\hline متوسطة & 3 & 1.128 & 3.14 & 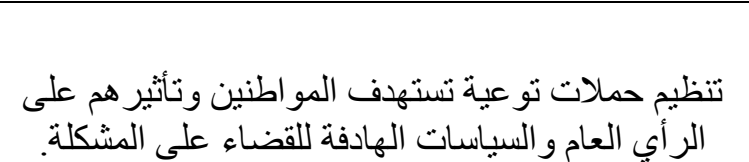 & 19 \\
\hline متوسطة & 1 & 1.143 & 3.26 & 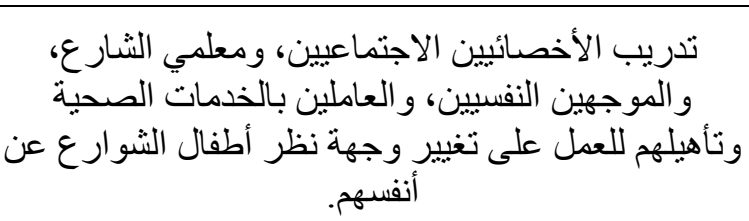 & 20 \\
\hline متوسطة & 7 & 1.003 & 2.94 & 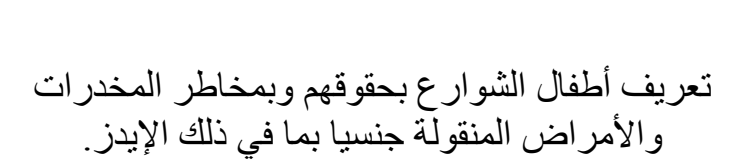 & 21 \\
\hline 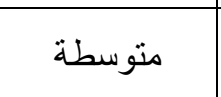 & 4 & 1.089 & 3.13 & 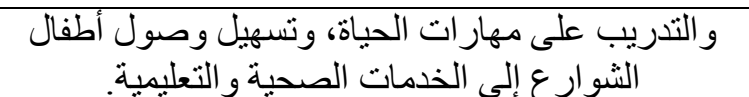 & 22 \\
\hline متوسطة & 2 & 1.201 & 3.15 & 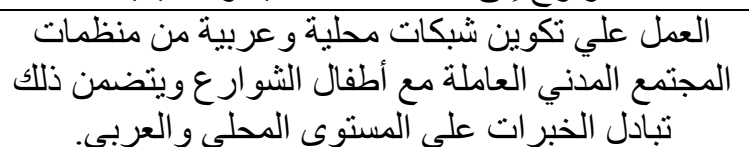 & 23 \\
\hline متوسطة & -- & .853 & 3.05 & المتوسط العام & \\
\hline
\end{tabular}

يتبين من الجدول السابق: أن المتوسط العام للبعد الثالث: الدور الثقافي جاء بدرجة استجابة (متوسطة)، وبمتوسط

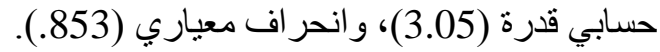

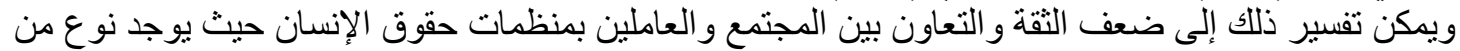

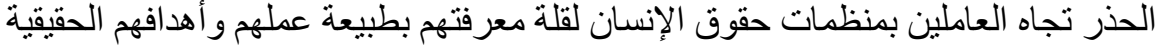

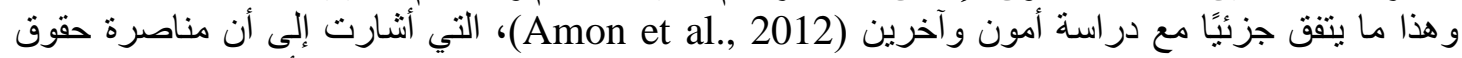

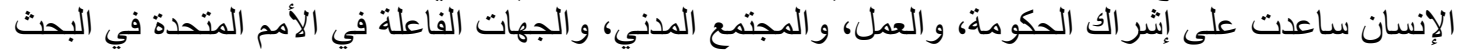
عن حلول مستدامة قائمة على الدليل بشأن مخاطر الصحة البيئية للأطفال العاملين.

$$
\text { ملخص النتائج وتوصيات ومقترحات الدراسة }
$$
أولاً ملخص نتائج السؤال الأول: الذي نص على: ما أسباب ظاهرة عمالة الأطفال؟ تبين مايلي: 


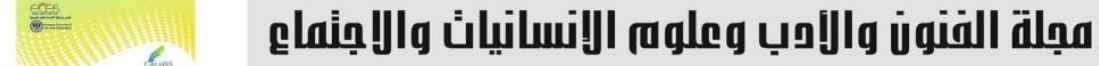 \\ Journal of Arts, Literature, Humanities and Social Sciences www.jalhss.com

- أن المتوسط العام للمحور الأول: أسباب ظاهرة عمالة الأطفال، قد جاء بدرجة استجابة (عالية)، وبمتوسط

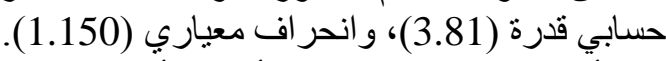

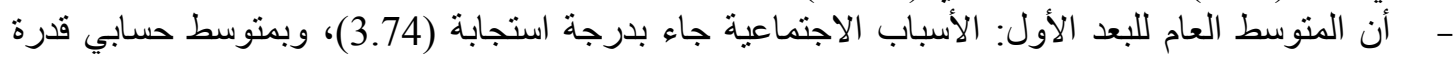
(1.338)، و انحر اف معياري (عالية).

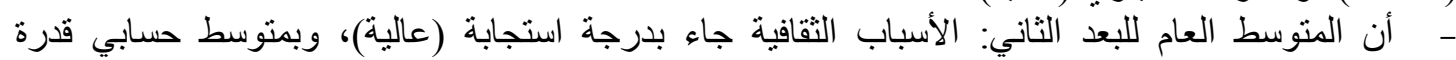

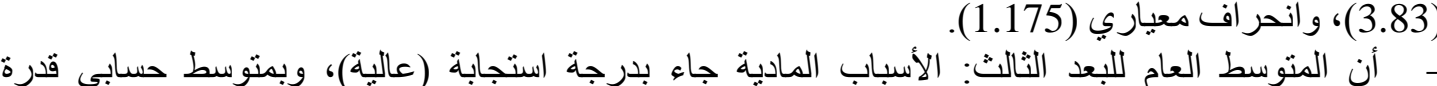
(3.90)، و انحر اف معياري (1.192).

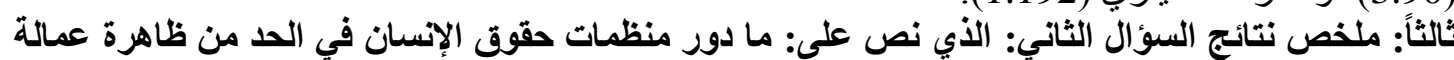

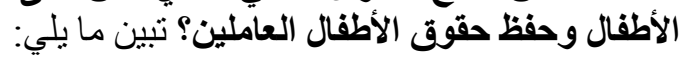

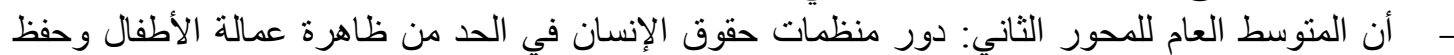

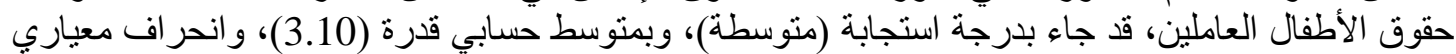
- أن المنتوسط العام للبعد الأول: الدور الاجتماعي جاء بدرجة استجابة (متوسطة)، وبمنوسط حسابي قدرة

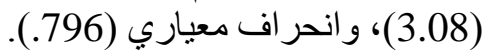

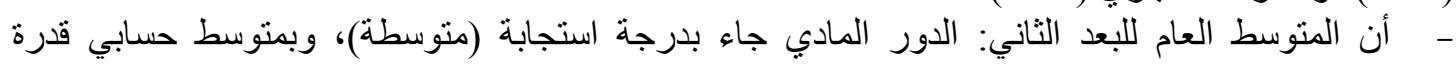
(3.27)، و انحر اف معياري (823.).

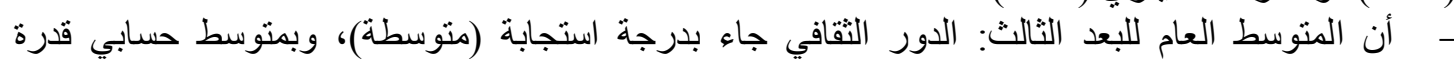
(3.05)، و انحر اف معياري (853.).

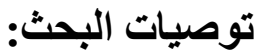

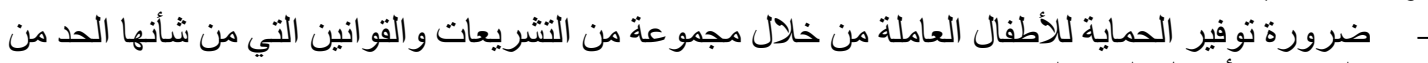
استغلالهم في الأعمال الغير الثر عية.

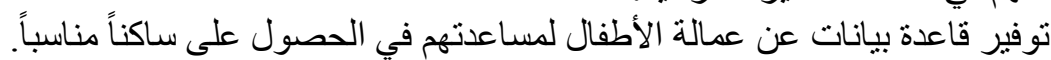

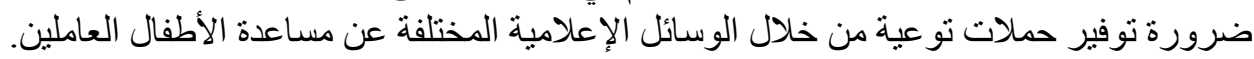

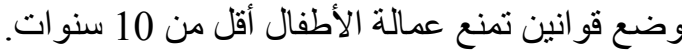

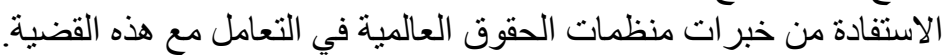

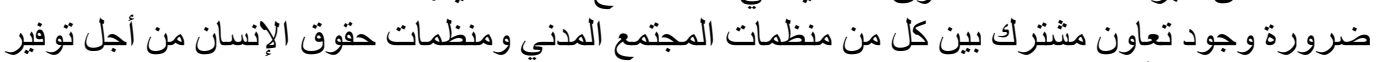
الضمان الاجتماعي للأطفال العاملة.

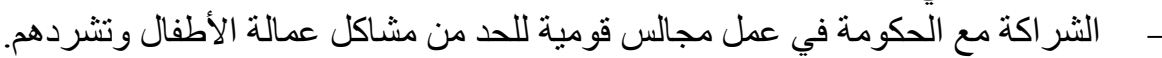

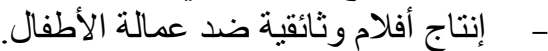

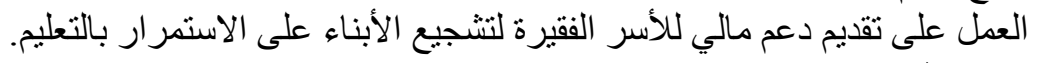
مقترحات البحث: عثى - - دور منظمات حقوق الإنسان في الحد من ظاهرة أطفال الثوارع.

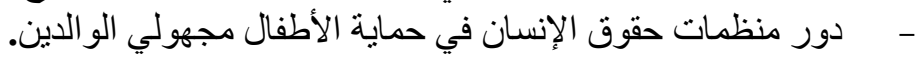

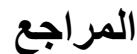
1. اتفاقية حقوق الطفل، اعتمدت وعرضت للتوقيع و التصديق و الانضمام بموجب قرار الجمعية العامة للأمم

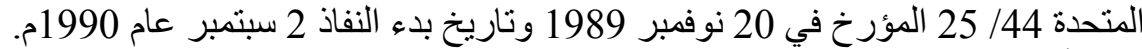

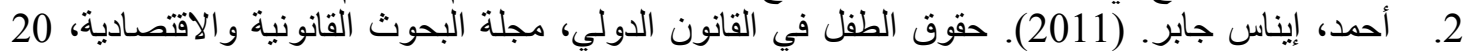

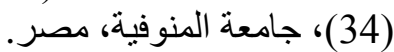
3. الأمم المتحدة (2004). دليل عمل للمجتمع المدني الحيز المدني المتاح للمجتمع المدني ونظام حقوق الإنسان في الأمم المتحدة، مكتب المفوض السامي، جنيف. 


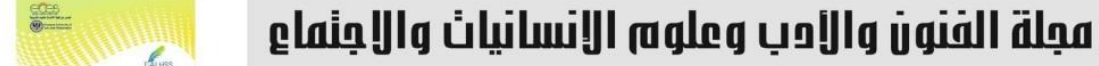 \\ Journal of Arts, Literature, Humanities and Social Sciences www.jalhss.com

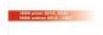

4. الحريري، محمد فتحي راشد. (2001). عمالة الأطفال في الوطن العربي، مجلة لطفولة العربية، الكويت، 2

5. الحمايدة، محمد عطبة. (2014). صورة منظمات حقوق الإنسان في الصحافة الفلسطينية "دراسة تحليلية وميدانية"، رسالة ماجستير غير منشورة، كلية الآداب، الجامعة الإسلامية، غزة الإنة فئان.

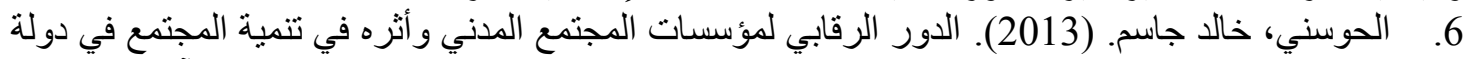
الإمار ات العربية المتحدة "جمعيات النفع العام در اسة حالة"، رسالة ماجستير غبر منشورة الكئ، كلية الآداب و العلوم، جامعة الثرق الأوسط. 7. درويش، محمود أحمد. (2018). مناهج البحث في العلوم الإنسانية. مصر: مؤسسة الأمة العربية للنشر

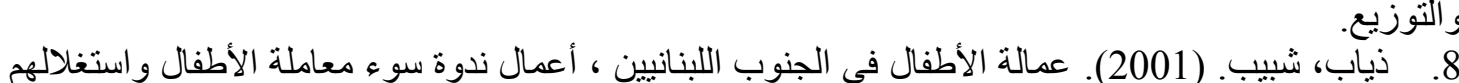

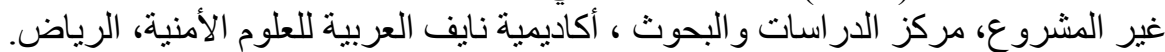
9. رزق الله، سلمى. (2015). و واقع عمالة الأطفال في الجز ائر دراسة ميدانية لعينة من الأطفال بولاية تبسة، الإنة

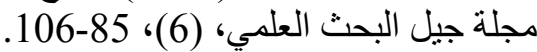

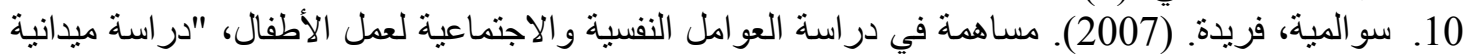

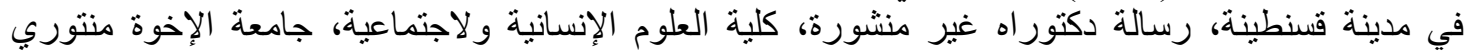
قسنطينة، الجز ائر. 11. شفلوت، خالد ذعار. (2013). نحو إستر اتيجية إعلامية لتعزيز ثقافة حقوق الإنسان في الرجتمع السعودي،

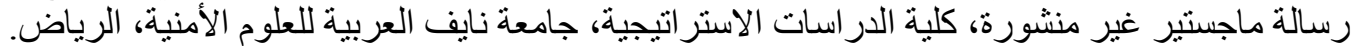

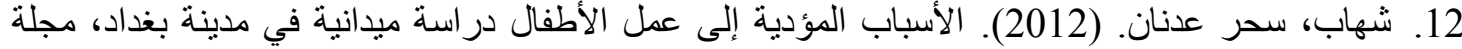

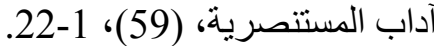
13. الثياب، محمد إبراهيم. (2006). الآثار السلبية الناتجة عن عمالة الأطفال من طلبة المدارس في محافظة اربد، رسالة ماجستير غير منشورة، كلية التربية، جامعة اليرموك: الئرة الأردن.

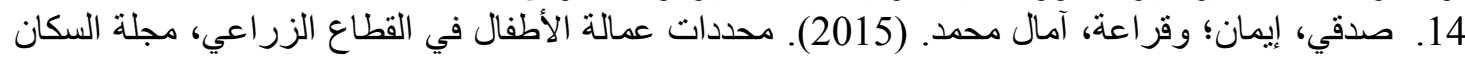

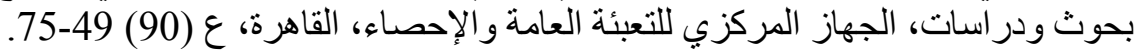

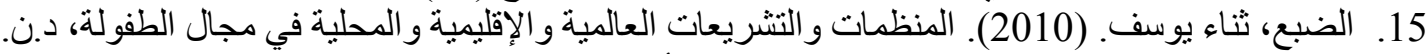

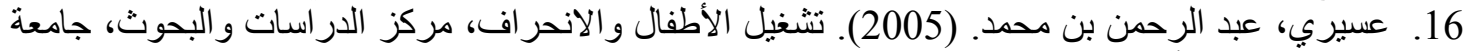

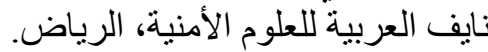
17. فدعم، محمد علي؛ محمد، نبيل جاسم. (2013). مخاطر الإنة عمل الأطفال في جمع النفايات در اسة ميدانية في

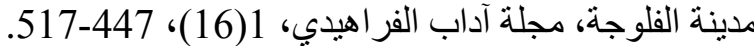
18. كاظم، سميرة عبد لحسين. (2011). عمالة الأطفال في العراق " الأسباب والحلول، مجلة البحوث التربوية

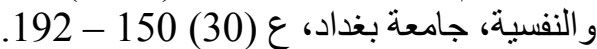

19. لجنة حقوق الطفل (2016). ردود المملكة العربية السعودية على قائمة المسائل، الأمم المتحدة، نيويورك.

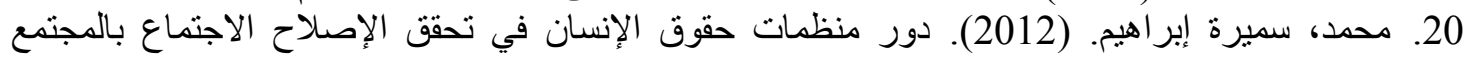

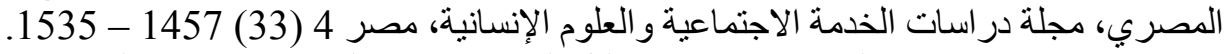
21. مكتب برامج الإعلام الخارجي (2012) دليل المنظمات الإتية غير الحكومية، وزارة الإنة الخارجية الأمريكية.

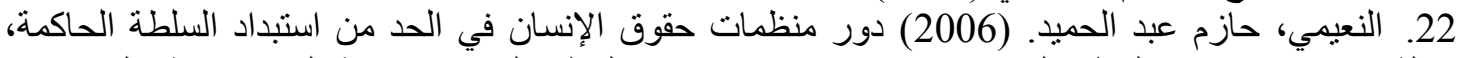

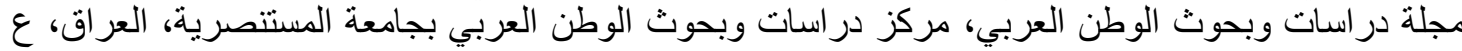

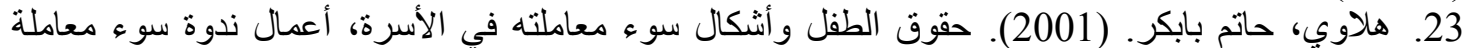

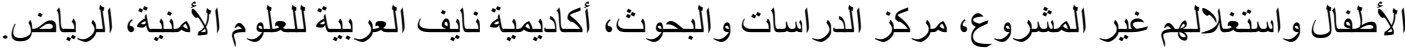

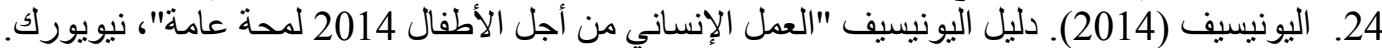




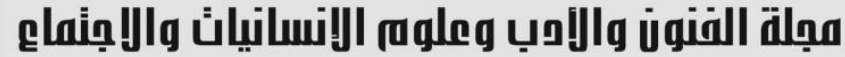 \\ Journal of Arts, Literature, Humanities and Social Sciences www.jalhss.com

25. Amon, J. J., Buchanan, J., Cohen, J.\& Kippenberg, J. (2012). Child Labor and Environmental Health: Government Obligations and Human Rights. International Journal of Pediatrics, 2012, 1- 9.

26. Estevez, K. (2010). Essays on Child Labor, Productivity, And Trade. Doctor of Philosophy, University of Florida, Florida, USA

27. Rai, R. K. (2016). History of child rights and child labour. Available online at http://menengage.org/wp-content/uploads/2014/06/History-of-child-rights-and-childlabour.pdf .

28. Wangusa, D. G. A. M. (2013). Multinational Corporations, Human Rights and Child Labour in Ghana (unpublished Master of law), University of Pretoria, South Africa.

29. Weston, B. H. \& Teerink, M. B. (2006). Child Labor through a Human Rights Glass Brightly. working paper no. 35. 